\title{
4 \\ Erich Wulffen and the case of the criminal
}

\author{
Birgit Lang
}

In 1927, the leading illustrated weekly Berliner Illustrirte Zeitung (BIZ) introduced its readers to the twenty-one most influential German criminologists of the day. Each was represented by a portrait photograph and a caption. The result was an iconography of experts in the burgeoning fields of studying, solving and writing about crime and criminals. Among the select group was Dr Erich Wulffen (1862-1936), Head of Department in the Saxon Ministry of Justice. ${ }^{1}$ The photo essay describes Wulffen as the author of several criminological works on sex crime. Actually, the former state prosecutor can be considered Wilhelmine Germany's first legal expert; with reference to Reiner Grundmann and Nico Stehr's definition of such an expert, Wulffen was undoubtedly a broker of knowledge between specialist discourse and the wider public in modern society. ${ }^{2}$ In addition, Wulffen wrote creative fiction on criminal psychology and legal reform.

During Wulffen's lifetime his published oeuvre included an unprecedentedly wide range of interdisciplinary cases: his case study compilations integrated sexological, psychiatric, psychoanalytic and anthropological insights to broaden the legal understanding of criminality. Through these compilations, Wulffen targeted the milieus of the court, the university and professionals within the penal system, but also the educated public. As a broker of knowledge between the law and the German people in the Wilhelmine and Weimar periods, Wulffen deserves special credit for shaping two new case modalities: the expert case and the case story. Wulffen's expert case studies relied on his privileged position and expertise to communicate new academic insights to the reading public. Wulffen's case stories were conceived as creative works of fiction with the purpose of illustrating certain criminal psychological insights gained in his academic work.

This chapter represents the most in-depth scholarly engagement with the breadth and nuance of Wulffen's case writings, and explores the intellectual contexts and case writing traditions that influenced Wulffen's use of case modalities: his humanist education, the cases and case writing 
traditions of the legal profession and forensics, and, most importantly, the role of the legal reform movement. Further, this chapter contextualises Wulffen's case writings in relation to his wider emancipatory project of educating a range of publics about the psychology of criminals - part of his attempt to further society's understanding of the criminal mind. Wulffen cleaved to his pedagogical project across the divide of the First World War, his sustained use of the case study genre defined by an ability to adapt case writings to particular audiences in Wilhelmine Germany. The period of the Weimar Republic proved more challenging to his larger project and to preserving the authority of what turned out to be a genre in crisis.

Like the fellow experts featured in the news magazine, Wulffen was a modern German mandarin. Fritz Ringer originally used the term 'mandarin' to reference the conservative nature of Germany's academic and legal elite, yet Wulffen was part of an overlooked group of legal reformers who sought to change the legal system from within. ${ }^{3}$ This progressive German intellectual elite aimed to close the ever widening gap between intellectuals and the German public and - during the Weimar era - stood in support of the Republic. If Wulffen's efforts on behalf of legal reform in the Wilhelmine era had entailed a range of professional and political difficulties, after the war the tables turned. He returned from exile in Zwickau to his home town of Dresden, where he began a stellar career, soon becoming the first Director of the Saxon State Court; in 1923 he was appointed Head of Department in the Saxon Ministry of Justice. English-language secondary literature in particular tends to emphasise Wulffen's political engagement as a member of the German Democratic Party, and his sustained interest in legal reform, thus situating him at the (albeit crumbling) liberal hub of Weimar Germany. ${ }^{4} \mathrm{He}$ is overwhelmingly viewed as one of the early twentieth century's discerning observers of the psychological effects of war, who was also able to present 'a multifaceted picture of members of the criminal class'. ${ }^{5}$

Such a portrayal contrasts with German historiography, where Wulffen is considered to have perpetuated Cesare Lombroso's biological theories, and to have disseminated stereotypes about criminals, furthering the dreaded biologisation (Biologisierung des Sozialen) which culminated in discriminatory and calamitous National Socialist policies. ${ }^{6}$ Yet, with the exception of female felons, Wulffen assumed criminality to be the result of three key factors: nature, nurture and fate. Accordingly, he took a sophisticated stance towards the Italian criminal anthropologist. That is, he summarised critical discourse concerning the reception of Lombroso in Germany and directly questioned Lombroso's theories. ${ }^{7}$ It is notable that Berlin psychiatrist, psychoanalyst and social reformer Otto Juliusburger (1867-1952) called Wulffen 'the ingenious successor of Lombroso, and the destined reformer of the brittle, doomed old penal system'. This genealogy did not contradict Wulffen's acknowledged distance from Lombroso, nor the interdisciplinarity of Wulffen's approach - Juliusburger was well 
aware of Wulffen's psychoanalytic leanings. ${ }^{8}$ Rather, Wulffen's works promised a new understanding of criminality and the criminal that transcended criminal anthropological insights. The pronounced differences between Lombroso and Wulffen were remarked upon by another contemporary, in a newspaper article which asserted one of the pillars of legal reform, namely that in contradiction to Lombroso's theories of the born criminal, Wulffen vindicates the point of view that criminality is latently present in every human being'?

The most satisfying way to describe Wulffen's position during the Weimar period is as a mediator between the opposing discourses of nature and nurture in Weimar criminology, which, as Richard F. Wetzell has noted, became increasingly dominated by biological explanatory models. ${ }^{10}$ Psychoanalysts and criminal psychologists focused their attention on criminality's effects on society, while criminal biology increasingly favoured biological explanations of crime. The criminal psychologist Wulffen sympathised with the former position - although he became disgruntled by psychoanalysis - while insisting on the relevance of biological factors, and adhering to a medical framework that he had referenced from the very beginning of his explorations of crime. The partial judgement of Wulffen as an adherent to notions of degeneration originates in Wulffen's post-war works on female criminality, in which he did revive some of Lombroso's theories. The fact that against the zeitgeist Wulffen viewed female felons as more degenerate than their male counterparts can be partly explained by his methodology. For better and for worse, Wulffen's empiricist framework and case-based methodology were not amenable to drastic paradigm shifts, since change could be accommodated only through the integration of new case material. Consequently, he was unable to integrate the paradigm shift represented by the emancipation of women in the Weimar era.

In addition, Wulffen's position as a writer of case studies became increasingly complicated due to the criminological fantasies of German society. The depiction of crime in Weimar popular culture, its 'dominance and prevalence as a cultural symbol' for the Weimar era, have long been noted in secondary literature. ${ }^{11}$ Todd Herzog has skilfully elaborated how, in the face of rising crime statistics, discourse about crime became all-encompassing and remained so even after 1924, once criminality declined. ${ }^{12}$ For Weimar journalists and many of their readers, criminals became a central symbol for the disrupted social order of the time. ${ }^{13}$ Correspondingly, the pervasiveness of criminality as a metaphor becomes obvious in the works of key Weimar intellectuals such as Walter Benjamin and Carl Schmitt. ${ }^{14}$ Herzog shows how the complex interweaving of documentary evidence with sensationalist cases, as seen, for instance, in Fritz Lang's cinematic oeuvre, led to a collapse of boundaries between fact and fiction. ${ }^{15}$ Such new developments brought into question Wulffen's educational project, in which fiction was put to serve criminology, although with a keen awareness of the limitations of conflating fact with fiction. In 
Wulffen's eyes this could only further the negative romanticising of crime and sexuality in contemporary society. Thus, during the Weimar era, this unorthodox thinker and practitioner of the case became a somewhat conflicted proponent of sexual modernity.

Indeed, the five-part definition of sexual modernity put forth by Harry Oosterhuis is particularly applicable to a study of Wulffen's ideas. ${ }^{16}$ Firstly, Wulffen believed sexuality to be an inevitable, natural force and one that greatly influenced criminality. Secondly, Wulffen's understanding of the effects of criminality and sexuality was psychological. Thirdly, as a criminal psychologist, Wulffen both classified and subverted the normal and abnormal, always assuming that anyone had the potential to become a criminal. He did, however, incontrovertibly favour the procreative norm over the pleasure and relational dimensions of sexuality. He believed the latter to be an important factor in the development of female criminality in particular, a topic that became central to Wulffen's late oeuvre. Despite the great success of his academic case compilations on criminal psychology and sex offenders, his views on female felons proved controversial among colleagues and his wider readership. Wulffen's views of sexual identity - the fifth criterion in Oosterhuis's definition - also grew increasingly conflicted with regard to the nexus between sexuality and criminality. This conservatism represented an 'occupational hazard' of sorts. Yet it is also expresses the dilemma of seeking to retain a balanced position in political and academic milieus that became increasingly radicalised on the one hand and biologised on the other.

\section{Embracing the case}

Wulffen's adoption of the case study genre in Wilhelmine Germany was extraordinarily successful. Above all, his academic case compilations hit a nerve and were well received in psychiatric, legal and progressive circles. Psychologie des Verbrechers (The Psychology of Criminals), first published in 1906 and reissued in 1908, was reviewed in all the major German newspapers. ${ }^{17}$ Similarly, Der Sexualverbrecher (Sex Offender) was reprinted three times in three months following its first publication in 1910. Hailed as the new Lombroso by Juliusburger, even reviews that were critical of some aspects of the work welcomed the new turn to casuistry. In his review of Der Sexualverbrecher, Carl Gustav Jung (1875-1961), founder of analytic psychology and at that time still a robust ally of Sigmund Freud, noted that the criminalistic casuistry presented by Wulffen, and the investigation of crime's psychological and sociological foundations, made the volume 'a valuable source' ('eine schätzenswerte Quelle') for future psychoanalytic enquiries in the field. ${ }^{18}$

The inspiration for embracing a genre that by the mid-nineteenth century had been pushed out of the realm of legal instruction at university 
originated from a desire to understand the driving forces behind criminality and to gain insight into the psyche of the criminal. In German legal history, such a way of thinking is inextricably linked with legal reformer Franz von Liszt (1851-1919), a younger cousin of the famous composer. Liszt had founded the Internationale Kriminalistische Vereinigung (or IK V, the International Criminological Association) in 1889, together with Belgian criminologist Adolphe Prins, Professor at Brussels University (later Vice Chancellor), and Dutch law professor Joost Adrian van Hamel. Liszt's scholarship in criminal law - widely disseminated through his 1881 textbook Das deutsche Reichsstrafrecht (German Imperial Criminal Law) - had already managed to shift the prevailing perspective from the authority of the law to that of the criminal act and its perpetrators. It opened positive law to a key new thought, namely that anyone could become a criminal given the chance: hence the degree of criminality should be judged by the perpetrator's potential for reform. Liszt consequently argued that opportunistic criminals should receive suspended sentences; reformable perpetrators should receive custodial sentences, with special measures taken for their resocialisation; repeat offenders should be held permanently in custody. In all, Liszt spearheaded the modern school of criminology and, as remarked by American legal scholar Arthur J. Todd in 1914-15, Germany's new penal code rested 'to no small extent upon the work of the I.K.V.' ${ }^{19}$

Wulffen's encounter with Liszt's modern school of criminology in 1903 had a palpable effect on his writings, and forms the beginning of Wulffen's new appreciation of the case study genre, a genre which had already defined his everyday work as a state prosecutor for several years. The passion and playfulness that Wulffen displayed in his engagement with this genre were mediated through forensic medicine and shaped by his humanistic education as well as his literary ambitions. Case writing gave voice to a crisis of expression that had accompanied Wulffen through his legal studies, glimpses of which are expressed in his 1913 roman-àclef Frau Justitias Walpurgisnacht (The Walpurgis Night of Mrs Justice). Publication of this novel saw Wulffen demoted from his post as State Prosecutor for Criminal Affairs in Dresden to the status of Councillor for Civil Affairs at the Magistrate's Court in provincial Zwickau. ${ }^{20}$ An unpublished autobiographical sketch dating to 1932 likewise reveals that Wulffen's first inclination had been to study not law, but literature. ${ }^{21}$ However, a fatherly intervention and the son's orientation towards the goals of his fellow high school students resulted in a decision to study law. ${ }^{22}$ In Wulffen's roman-à-clef the main character, Wartenberg, is easily identifiable as the author; for instance, Wartenberg - just like Wulffen in 1908 - delivers a lecture titled 'Der Strafprozeß - ein Kunstwerk der Zukunft' ('The Criminal Trial as a Future Work of Art'). Wartenberg 'went with a full, warm heart into [the] unknown academic field [of law]', only to realise that 'matters of the heart were of no relevance'. ${ }^{23}$ The novel criticises the 'stuffy' court systems of the time, as well as German 
legalese, renowned for its impenetrability. When Wartenberg seeks to challenge legal writing conventions he is rebuffed:

Now he had to hear that he had no clue about legal writing style. From the corrections of the local judge he saw what was needed. He had stressed the emotional and lively side of the criminal event. That was not allowed. ${ }^{24}$

Likewise, the autobiographical sketch reports how, during his time as an assessor, Wulffen was criticised for his ornate writing style, which not did not seem austere enough. ${ }^{25}$

According to Wulffen, his literary and theatrical ambitions subsided only after his encounter with representatives of the German division of the IKV, an occasion he describes as a 'decisive turning point' ('entscheidende Wendung') in his life, at age forty-one. In 1903, Wulffen had been invited to the association's ninth German gathering, in Dresden, and he reported on the event for the scientific supplement of the most important local daily newspaper, the Dresdner Anzeiger. ${ }^{26}$ In the modern school of criminology Wulffen found the answer to his question of whether law and art could complement one another. Apparently, the insight that criminal proceedings could and should utilise analysis of the 'interior life and character, motif and environment of the perpetrator' meant that Wulffen could invest his imaginative powers in his work, rather than into separate creative ventures. ${ }^{27}$ The same insight enabled him to reframe works of German and world literature as 'textbook examples of criminal psychological literature'. ${ }^{28}$ Friedrich Schiller and Johann Wolfgang von Goethe and their engagement with criminality held a special fascination for Wulffen throughout his career, and in time he put these figures into the service of criminology. ${ }^{29}$

Two years after his first encounter with the modern school of criminology, Wulffen's first published discussion of a legal case (1905), 'Ein kriminalpsychologisches Experiment' ('A Criminal Psychological Experiment'), highlighted the shift in his understanding of crime and his new affiliation with the burgeoning field of criminal psychology. Published in Gustav Aschaffenburg's well respected journal Monatsschrift für Kriminalpsychologie und Strafrechtsreform (Monthly Journal for Criminal Psychology and Legal Reform), the case history essays the possibilities for ethically influencing the life of a 'criminal character'. Wulffen presents the example of twenty-six-year-old 'Arthur Br.', who had been wrongly convicted of theft as a repeat offender. Under Wulffen's administration the case had gone to retrial and the accused was acquitted, but Arthur Br. approached Wulffen, seeking to regain his status as a prisoner, because life in prison had provided him with 'food, work and order'.${ }^{30}$ Wulffen was eventually able to place Arthur Br. with a Dresden welfare association and even invited Arthur Br. to his own home for the Christmas celebrations. Nonetheless, when the court financially compensated Arthur Br. for his wrongful imprisonment, he quit his job, paid his debts and left for 
Berlin, only to return once depleted of his funds. By way of a conclusion, Wulffen states that 'ethical interference' ('ethische Beeinflussung') might bring temporary relief, thus exerting some positive influence. Yet his verdict is unambiguous:

Disposition, education and fate have made him [Arthur Br.] what he is, and what he is destined to be. There is no escape from these three sisters of fate. Weakness of the will is his allotted part, as other people suffer from different organic failures. So help him God! ${ }^{31}$

Wulffen's first case history written for an educated and professional public exemplifies the conflation of scientific and moral categories of analysis that Silviana Galassi considers typical for Wilhelmine criminology. ${ }^{32}$ It also discloses the empathy of a state prosecutor and - in this case at least - Wulffen's exceptional goodwill. The same article underlines contemporary prejudice towards former convicts, and presents a 'best practice' case: Wulffen outlines how he arranges for Arthur Br.'s wages to be paid daily, and advises him to open a savings account, presenting his subject in a likeable light. He also emphasises that, based on aspects of the circumstantial evidence, and other details of the case, any other court would have convicted Arthur Br., since errors of justice are inherent to the justice system. Wulffen's stern assessment of the inevitable fate of Arthur Br. could be rendered more generously: the facts that Arthur Br. paid off his debt with the compensation monies, and did not commit another criminal offence, might be interpreted together as an indication of reasonable success.

Wulffen's turn to the case study genre was unusual for someone in his profession. This seems surprising, considering that legal cases and related case studies represented an integral part of judicial life. As a state prosecutor in the German legal system, Wulffen came into contact with a whole range of case files; he was responsible for the preparation of a great variety of such files in connection with the three-stage German court process. To this day, the process comprises an initial investigatory phase (Vorverfahren), the decision-making process if the case should proceed to trial (Beschlusskammer) and the trial itself (Hauptverfahren). ${ }^{33}$ In the role of state prosecutor, Wulffen was actively involved in all three stages, collecting, examining and partly composing or supervising the composition of relevant materials and organising these neatly into a court file register, where the various entries were made chronologically: the record of interrogation of the accused; witness statements; on-site inspections; the results of the Beschlusskammer; as well as contributions from courtappointed experts, and from forensic, psychiatric and police reports; and any other significant incriminating materials, such as letters or diaries.

Despite the prevalence of case studies in the everyday professional life of the court, legal journals refrained from publishing casuistry. As a consequence, journals important to the German legal profession, such as the generalist Deutsche Juristen-Zeitung (1896-1919) (Organ of German 
Jurists), in which Wulffen published his views on legal reform, were not publishing casuistry. Der Gerichtssaal (1849-1919) (The Courtroom), a progressive journal dedicated to popular law and scientific practices, presented case writings only rarely. Until Wulffen's arrival in criminal psychological circles, even Gustav Aschaffenburg's influential journal Monatsschrift für Kriminalpsychologie und Strafrechtsreform (Monthly Journal for Criminal Psychology and Penal Reform) presented case studies in a designated section titled 'Sprechsaal', a 'speakers' corner' concerned with day-to-day judicial business. Earlier criminal psychological works such as Hans Gross's Kriminalpsychologie (1898) remained widely discursive and did not include case materials. This lack was a direct consequence of the fact that the German legal system was (and is) not case-based like the common law, but was defined through abstract and conceptual reasoning. While legal change in a common law system is driven by precedent, and thus makes casuistry highly relevant to legal professionals, civil law negotiates changes through federal parliament. Within the German legal system, judges have traditionally had greater influence than those in common law legal systems.

When Wulffen himself set about writing academic case compilations, he used the generic frame provided by forensic medicine. Richard F. Wetzell has helpfully outlined the mutual benefits arising from the medicalisation of penal reform and sees 'the penal reform agenda ... significantly influenced by medical theories and practices'. ${ }^{34}$ The combination of discourse and casuistry that defined forensic textbooks became determinative for Wulffen's academic case studies as well. The first reference to forensic psychiatry in Wulffen's oeuvre can be found in an eleven-page discussion of the treatment of legal issues in the play Rose Bernd, a 1903 drama by naturalist German writer Gerhart Hauptmann (1862-1946), inspired by Hauptmann's jury service on the case of child murderer Hedwig Otte. Wulffen's discussion explains the legal context of the drama and elaborates on Hauptmann's inclusion of psychiatric knowledge of female hysteria. ${ }^{35}$ In this context, Wulffen quotes leading psychiatrist August Cramer (1860-1912), then director of the psychiatric clinic in Göttingen, and his work Gerichtliche Psychiatrie (Forensic Psychiatry), which was written for physicians and lawyers, and contained a range of case studies. Thereafter, all of Wulffen's criminal psychological textbooks followed the forensic model.

Criminal psychological case compilations differed from medical case studies through the evidence provided, which, as expected, originated from medical and legal discourse but also included expertise from fields such as criminal statistics, criminal anthropology, psychoanalysis and literature. A review of Der Sexualverbrecher by Dresden lawyer Dr Glaser underlines, for instance, the value of the new psychoanalytic aetiology that was championed by Wulffen for the world of law. To conceptualise crime and criminality through the lens of sadism, masochism, fetishism and homosexuality, in combination with social factors, had the advantage 
of pointing out phenomena which, 'especially for the judge, were not considered enough, if at all. And it sheds light into the gaping abyss of criminal souls, that even today remain murky and incomprehensible to many'. ${ }^{36}$

In twenty-first-century secondary literature, this medley of knowledge is usually ignored, or criticised. Well known historian of sexuality Volkmar Sigusch considers Wulffen's works unscientific, while Sace Elder calls Wulffen 'an indefatigable synthesizer and popularizer of criminal science (often at the expense at scientific rigor)'.${ }^{37}$ Galassi has argued more generally that the insufficient academic professionalisation opened the door to the political appropriation of criminology by National Socialism. ${ }^{38}$ Yet such criticism does not explain the appeal of Wulffen's compilations for his contemporaries, which lies in the interdisciplinary method now disparaged. Reviewers of Wulffen's works were most impressed by his ability to synthesise several discourses from a range of monographs and professional journals, and to provide much-needed reference works. ${ }^{39}$ Thus, the overall goal of these case compilations was to educate readers and to sharpen expert eyes by making available comparable casuistry and new explanatory frameworks. They provided professional and educated readers with an archive of casuistry, allowing them to make more informed judgements about criminals and their crimes.

Like medicine, criminal psychology needed to find laws for irregular phenomena that were embodied by a specific group of people. ${ }^{40}$ Such an undertaking required a range of theories; in the case study compilation these were represented through broad discursive-scientific narratives. The individual cases then provided evidence for these theories, while also serving as illustrations. Neither doctors nor criminal psychologists assumed that any single individual would fit their categories perfectly. As Wulffen outlines in his contested Das Weib als Sexualverbrecherin (Female Sex Offenders), "the individuals questioned are never typical men or women, but - according to biological knowledge - can only ever be individuals with a greater or lesser element of the characteristics of the opposite sex'. ${ }^{41}$ This also implies that a range of theories could coexist, although they did not always seamlessly integrate.

Yet Wulffen did not stop at the creation of case study compilations. Against the backdrop of the crisis of legitimacy surrounding the German legal system in the late nineteenth and twentieth centuries, accused of class bias (Klassenjustiz) and of being disconnected from 'the real world' (Weltfremdheit), Wulffen also developed the case study genre beyond criminal psychological case compilations. ${ }^{42}$ His choice of register for these more unusual case modalities - that is, his expert legal commentaries and crime novels - were informed by case knowledge he had acquired during his education in a humanist gymnasium. Wulffen attended the renowned Dresden Kreuzgymnasium (literally, 'High School of the Cross'), one of the oldest German schools, dating to the fourteenth century. Like all graduates from Wilhelmine gymnasia, he was familiar with the case 
as a rhetorical device through the study of classical literature. As a gymnasium student he would have learned about the necessity of aligning an illustrative case with his main argument in order to remain convincing; from Cicero in particular he learned to address his audiences in different registers, whether to inform, to move or to delight. ${ }^{43}$ As a writer, Wulffen made a precise and deliberate appeal to his readership. Through his criminal psychological case compilations he aimed to inform; readers were delighted by his expert case studies of criminals, as well as his literary and cultural histories of the representation of sexuality in art and literature. His case stories aimed to move the wider general public and to illustrate criminal psychological knowledge. In all three case modalities he aimed to convey the insights of criminal psychology.

Wulffen's key concerns are easily discernible and shaped by his legal reform background and his close affinity to the modern school of criminology. While Wulffen might appear a 'Jack of all trades', if he did include a wide range of evidence in his case studies he did so with the self-confidence of a legal professional. Unlike the common law system, where evidence must conform to a number of rules to be admissible, the legal system in Germany accepts as evidence whatever the judge sees fit to admit. Wulffen differed from fellow members of the judiciary in that he showed a genuine preoccupation with the emotional and interior life of criminals. This could not be expressed in his legal studies until his encounter with the modern school of criminology, and subsequently with the case study genre, which made it possible for Wulffen to explore a legal language that he felt comfortable to speak.

\section{Exceptional criminals: con men}

Throughout his career, Wulffen retained a deep concern with exceptionally intelligent criminals, especially con men. Analysis of Wulffen's case writings on the topic brings to light ways in which he fashioned different case modalities. The profile of the con man as a type of criminal seemed to Wulffen different from that of other offenders: criminals were usually considered to be below average in intelligence, already facing learning problems while in the educational system, and liable to experience difficulties in logical thinking. Con men operated in a different league. ${ }^{44}$ Their deceptive nature, their theatrical talents and their methods for seducing their victims, while loved by the public, made them an especially pertinent subject of investigation for criminal psychology. Imposture was the topic that inspired Wulffen to write his first book-length expert case study - on Georges Manolescu (1871-1908), con man and hotel thief extraordinaire - as well as several fictionalised case stories inspired by the Manolescu case. The most successful of these was Wulffen's 1917 best-selling crime novel Der Mann mit den sieben Masken (The Man with the Seven Masks), which was made into a film in 1918. 
A comparison of expert case study and case story showcases Wulffen's ability to adapt case writings to particular audiences in an attempt to educate them, as well as to communicate criminal psychological insights to a wide readership. Wulffen's pioneering work on con men represents the earliest academic investigations of this phenomenon in the Germanspeaking world and it preceded relevant psychoanalytic investigations by nearly two decades. If psychoanalysis has contributed most to the psychological understanding of imposture, it was also instrumental in sidelining Wulffen's earlier insights, as the following explorations show.

By the early twentieth century, Wulffen's interest in legal reform, and his attempt to close the communication gap between the court and the public, had led him to deliver public lectures, write contributions to academic and legal journals, and write to newspapers on the topic of criminality. ${ }^{45}$ Wulffen's first extensive expert case study, Georges Manolescu und seine Memoiren. Kriminalpsychologische Studie (Georges Manolescu and His Memoirs: A Criminal Psychological Study) was published in 1907, following the publication of Manolescu's memoirs in 1905 and $1907 .{ }^{46}$ The media hype surrounding these memoirs represented an ethical challenge, due to the romanticisation of criminality, but also an opportunity. The memoirs allowed Wulffen to develop new insights into the workings of a fascinating criminal mind, to build his profile as an expert in legal matters, and to promote the criminal psychological cause beyond the academic sphere. They also permitted Wulffen to remind the German public of the detrimental consequences of Manolescu's actions, and of the unstable source of their excitement. After all, Wulffen believed that those members of the German public who so feverishly consumed the works of the suave Romanian hotel thief were also easily victimised. It was Wulffen's view that, due to their love of everything foreign, Germans were especially credulous and susceptible to imposture. ${ }^{47}$

Manolescu was one of the first convicted criminals in Germany to publish his memoirs with a reputable and entrepreneurial publisher, Paul Langenscheidt. This made the memoirs accessible not only to a specialised readership but, simultaneously, to a general audience. Up to this point, case studies by convicted criminals had been published in academic contexts, notably in Lombroso's Archivio di Psichiatria (1880-1909), which contained a series of autobiographical texts by psychiatric patients, together with Lombroso's extensive commentary - sometimes without the patient's awareness of the publication. A more religious framework of penance was the context for publications edited by prison chaplains, such as Johannes Jaeger's Hinter Kerkermauern (1906). In British autobiographies of convicted criminals, the theme of redemption played an important role until the $1930 \mathrm{~s}$, when a shift occurred towards a more psychological interpretation, though it still included the notion of redemptive suffering. ${ }^{48}$ The more psychological narratives helped to curb the potential hype surrounding these works and gave them an aura of respectability. In the German context, a shift to a psychologising framework took place much earlier. 
In retrospect, such publication practices certainly appear ethically questionable, and represent key examples of the control wielded by clinics and prisons over their subjects, as emphasised by Michel Foucault. Yet Manolescu's publication of his memoirs for a general readership through Langenscheidt involved its own ethical challenges, including the romanticising and trivialisation of crime in general, and secondary trauma caused to victims. It also yielded financial and potential emotional benefits to a convicted criminal who had escaped from psychiatric institutionalisation in Germany, and who eventually settled as a free man in France, where he died in $1908 .^{49}$

Wulffen's study of Manolescu negotiated in new ways the worlds of law and the public sphere and made Langenscheidt the publisher of the first legal expert case study. Wulffen set forth a new kind of in-depth analysis of the character of a con man in German criminology. Written in a measured tone, and in a language that was free from legal jargon, this expert case study presented a thoroughgoing character analysis of Manolescu himself, and explained the impact of Manolescu's deeds on his victims (including Manolescu's wife and daughter). Wulffen brought to this analysis more than just an inquisitive mind and a deep understanding of the German legal system. As a state prosecutor, he was a respectable public figure. Through his professional role he enjoyed privileged access to a wide range of police and court files often unavailable to other contemporary writers and crime reporters such as Paul Lindau (1839-1919), Hans Hyan (1868-1941) or Paul Schlesinger (1878-1928). ${ }^{50}$ These well known crime writers were obliged to request permission from the local court for access to court files and they were unable to order files from other jurisdictions, while Wulffen consulted relevant judicial and police records from other European countries. ${ }^{51}$ Wulffen's high standing might explain also why the megalomaniac Manolescu agreed to correspond with him. In his memoirs Manolescu acknowledged his attraction to the "cat and mouse' game he played with judicial and penal authorities as well as the police; according to Wulffen, Manolescu even offered his own remains to Lombroso, revealing his enthralment with the word of criminology. ${ }^{52}$

By today's standards, Manolescu fulfils all assessment criteria of the Hare Psychopathy Checklist - Revised (PCL-R); since the 1990s this psychological diagnostic tool has been commonly used to assess the presence of psychopathy in individuals. Judging from Manolescu's autobiography and Wulffen's study, Manolescu was superficially charming, possessed a grandiose sense of self-worth, lied pathologically and was cunning and manipulative. His affective capacities were limited and he lacked remorse; he was emotionally shallow, lacked empathy and failed to accept responsibility for his actions. His lifestyle was parasitic and revealed a need for stimulation. He lacked realistic long-term goals (apart from becoming rich), was impulsive and irresponsible. In all, he demonstrated a range of antisocial behaviours, as well as promiscuous sexual behaviour. 
Aspects of Wulffen's criminal psychological language for describing Manolescu's behaviour prefigure this current vocabulary of psychopathology; he includes biological and environmental explanations. To Wulffen, Manolescu unambiguously presented as a degenerate maniac, that is, a person whose mental illness is marked by periods of great excitement, delusions and over-activity, and who is missing the physical, mental or moral qualities considered normal and desirable. Manolescu's Romanian origins and his southern race played a key role in Wulffen's profiling of the con man, and was used to explain the degree of his mania, factors that helped Wulffen to situate Manolescu's crimes in line with contemporary forensic notions of criminality. Yet to Wulffen the most important reason why Manolescu was 'in reality even more interesting and of greater significance than the memoirs reveal him to be' lay in the psychological make-up of Manolescu's personality. ${ }^{53}$

Wulffen's expert case study includes a detailed reconstruction of Manolescu's life history, based on police and judicial files, the original French manuscripts of the memoirs, newspaper articles and other materials, which are compared in detail with statements made by Manolescu in his autobiography. Wulffen verifies Manolescu's statements where possible, unveils his lies, describes Manolescu's omissions in his memoirs and corrects his exaggerations. ${ }^{54}$ In addition, Wulffen questions Manolescu's self-image as energetic, disciplined, self-controlled and determined. These were largely figments of Manolescu's imagination - so Wulffen argues with Manolescu's character defined by an 'instinctual primordialism' that led Manolescu to reinterpret his actions retrospectively, and to embellish his explication with grandiose notions of self. ${ }^{55}$

Wulffen's psychological insights into Manolescu's psyche seem considerable. They pre-empt and parallel psychoanalytic insights on imposture that to this day dominate in the relevant specialist literature. For example, his insights parallel Helene Deutsch's 1955 case study of imposture, in which she states:

Reading his [the patient Jimmy's] life history, one sees that he was perpetually in pursuit of an identity which would do justice to his narcissistic conception of himself in terms of 'I am a genius,' and which at the same time would serve to deny his own identity. This denial of his own identity appears to me to be the chief motive for his actions, as is true in the case of other impostors. ${ }^{56}$

Similarly, Wulffen convincingly argues that Manolescu fails to take responsibility for his actions, and lacks ethical feelings for victims of his crimes. ${ }^{57}$ Two years before Freud described the 'family romances' of neurotics, and half a century before Phyllis Greenacre identified the compulsive pressure to live out the 'dominant and dynamically active family romance' as one of three constitutive factors in the personality of impostors, Wulffen describes Manolescu's fixation on his family romance, repeated in his relationships with his wife and daughter. ${ }^{58}$ 
The difference between the criminal psychological analysis and psychoanalytic analysis of imposture is important to discern, because it helps to explain the ways these two fields of knowledge developed. Specifically, a comparison between Wulffen's works and the first exploratory case study of the phenomenon by German psychoanalyst Karl Abraham in 1925, 'Die Geschichte eines Hochstaplers im Lichte psychoanalytischer Erkenntnis' ('The History of an Impostor in the Light of Psychoanalytical Knowledge'), sheds light on the differences in methodology and the mutual reception of criminal psychology and of psychoanalysis. ${ }^{59}$ As mentioned, Wulffen's aetiology was based on psychoanalytic categories. Indeed, the minutes of the Vienna Psychoanalytic Society, or WPV, reveal that his reception of psychoanalytic theories was noted in psychoanalytic circles. ${ }^{60}$ However, in the mid-1920s, when psychoanalysts turned their investigations towards the area of the law and criminality, considerable tension arose between criminal psychologists like Wulffen and psychoanalysts like Abraham. Abraham sidelined Wulffen's body of work, and yet the insights developed in the two fields of knowledge are complementary. ${ }^{61}$

Abraham's 1925 case study describes the fate of a con man who overcame his condition - through a marriage that represented the "complete psychological fulfilment of an infantile wish-situation'. ${ }^{62}$ Wulffen also contemplates the reasons behind Manolescu's marriage, but does not focus on the positive influence of this marriage, which seems to have enabled Manolescu to abstain from committing criminal acts for almost a year. Rather - and here lies a key difference in approach - Wulffen describes the detrimental effects of the marriage on Manolescu's wife and daughter. While Abraham focuses on the childhood fantasies of his subject of study, Wulffen engages with Manolescu's adult fantasies. According to Wulffen, Manolescu remained fixated on his family (his marriage to a German countess can be interpreted as wish fulfilment) but the 'affect for his daughter remains phantasmatic, in that it is not directed in a real, practical, and caring manner towards his daughter' ${ }^{63}$ Instead, Manolescu 'torments his family and then cries about the fact like a child' ${ }^{64}$

The respective case studies authored by Wulffen and Abraham lie nearly twenty years apart, and their contrasting focus can be explained in part by the severity of symptoms presented by the two criminal subjects in question, and partly by the different methodology the intellectuals used. Wulffen explains Manolescu's disposition with considerable psychological insight, and underlines the impacts of Manolescu's behaviour on his family and society in general. He develops the language of criminal psychology further through a contemporary medical framework that identifies Manolescu as an incorrigible criminal. Abraham steers his argument in another direction. Although he states that his article represents a bridge between psychoanalysis and criminology, he takes a decided stance in relation to degeneration, arguing that "we should not overestimate heredity, "degeneration" in its role in the genesis of 
asocial and criminal behaviour'. ${ }^{65}$ Rather, concludes Abraham, his case represents another instance that strongly suggests a fundamental role played by early childhood, while the phenomenon of the con man is usually explained through the degeneration model. ${ }^{66}$

Abraham's comment on the prevalence of the degeneration model in criminology might be read as an allusion to Wulffen's Manolescu study, or to his 1923 study Die Psychologie des Hochstaplers (The Psychology of the Con Man), which again contained biological but predominantly psychological insights, and was published two years before Abraham's article. Otherwise Abraham chose to sideline Wulffen altogether. There would have been ample opportunity to relate Wulffen's psychological insights in his own study, but Abraham's article constitutes a notable occasion on which a psychoanalytic thinker skated over a body of knowledge first explored through criminal psychology. Abraham preferred to reference the work of Austrian school teacher and psychoanalyst August Aichhorn (1878-1949), who was at the time working with troubled youth. Thereby Abraham constructed a narrative of hope and change, rather than what he perceived to be a narrative of stigmatisation. As discussed below, this strategy might have contributed to Wulffen's alienation from the formerly revered Viennese school of thought.

Wulffen did not yet have at his disposal the psychoanalytic vocabulary for analysis of imposture, but his description of Manolescu seems closer to later psychoanalytic explanations of the phenomenon than to the biological framework otherwise employed in Georges Manolescu und seine Memoiren. He foreshadowed a relational approach, which emerged predominantly in American psychoanalytic thought, first through psychiatrist Harry Stack Sullivan (1892-1949) and then through the relational turn of the 1980s. Conversely, Abraham focused solely on the subject of his case, gave informed speculations about the latter's childhood fantasies - he had not able to conduct psychoanalysis - but did not consider the implications of the marriage for the spouse and her family. His sidelining of Wulffen might have been a reaction to the shift towards the biological model in psychiatry, but also an attempt to claim new psychoanalytic territory, at the cost of a loss of knowledge.

\section{Der Mann mit den sieben Masken as a case story}

Wulffen's expert case studies and academic case compilations aimed to convince an educated public through insightful observation and by means of argumentation. His case stories, on the other hand, illustrated the criminal psychological arguments developed in his analytical work, educating the wider public through their recreational reading and by means of catharsis. Poetic licence also allowed Wulffen to explore case materials that were inappropriate in his academic and expert case studies: 
he could write so as not to reveal personal details and further stigmatise the victims of impostors.

Wulffen's case stories of imposture comprise a range of works, the most important of which is his 1917 crime novel Der Mann mit den sieben Masken. Wulffen wrote his crime novels during his period 'in exile', after his transfer to Zwickau between 1914 and 1919, following publication of his roman-à-clef. Each novel represents a mixture of legal thriller and police procedural, mostly featuring as the main investigator a state prosecutor who is interested in criminal psychology. ${ }^{67}$ Three works stand out for their success: Der Mann mit den sieben Masken focuses on imposture; Die Kraft des Michael Arbogast (The Powers of Michael Arbogast), published in the same year, describes the fate of a former criminal who fails once his previous conviction becomes known; and Die geschlossene Kette (The Closed Chain) (1919) problematises conviction for murder where the evidence is only circumstantial. Each of these works illustrates insights that Wulffen had gained in his academic case studies, and makes them palpable to a reading audience beyond the educated middle class.

Der Mann mit den sieben Masken became Wulffen's greatest success as a writer of fiction. The work was first printed as a serialised novel in 1916 in the Berliner Tageblatt, which together with the Vossische Zeitung was the most influential Berlin newspaper at the time. ${ }^{68}$ Der Mann mit den sieben Masken then reached four reprintings with publisher Reissner in the first year of its publication in 1917, and was reprinted as a serialised novel in the Protestant nationalist München-Augsburger Abendzeitung. ${ }^{69}$ In August 1918, Wulffen was approached by Messter Film Berlin concerning the film rights to the story. Within five weeks the film was adapted for the screen by Danish film actor, director, producer, silent-movie pioneer and creator of a Sherlock Holmes series Viggo Larsen (1880-1957); Wulffen provided the film script. ${ }^{70}$ Lastly, in 1922 and 1928, renowned publisher Ullstein, one of the most active and successful German publishers of popular literature, included Der Mann mit den sieben Masken in the first and second incarnation of the Yellow Series, which focused on crime, adventure and society novels, and targeted a mass audience.

Der Mann mit den sieben Masken was well received in legal as well as progressive liberal circles, and more generally by the wider German public. In an essay on the nature of imposture the then Director of the Brandenburg State Court Albert Hellwig (1880-1950) stressed the importance of Wulffen's achievement.

I do not feel the urge to comment on the literary value of [ $t$ ] his work. From the perspective of criminal psychology, however, without doubt we are dealing with an extraordinarily instructive book, which nonetheless forms a compelling and good read [Unterhaltungslektüre] as well. The expert will recognise the original material from which the poet-criminologist draws [i.e. the Manolescu case]. It is remarkable how Wulffen has utilised his academic sources, how he created poetically from reality, without negating the criminal psychological meaning of his account. ${ }^{71}$ 
Other reviews focus on the story-line in greater detail, especially on the most evocative protagonist of the crime novel, state prosecutor Dr Sperl, who, like other characters in the book, falls victim to the charms of con man Niklas Györki. While at least partly conscious of his fascination with Györki, through a mixture of epistemophilia and insecurity, the alltoo-human Sperl becomes deeply involved in the con man's psychological game, ultimately compromising Sperl's own ethical boundaries. Sperl's complicity in this relationship makes him vulnerable, and leads him to commit suicide.

All reviews comment on the scene in which Györki 'reels in' the enthusiastic criminal psychologist who believes himself capable of analysing and convicting the con man. The Dresdner Volkszeitung attests to the importance of this incident, while Helene Stöcker's progressive feminist journal Die neue Generation concedes as weaker those scenes in which Wulffen introduces his criminological knowledge: 'it seems unrealistic that a state prosecutor will engage so deeply and intimately in conversation with a convicted criminal that the latter is allowed to declaim scenes from Richard III or Hamlet in order to explain his psychological considerations, and that in turn the accuser feels so defeated that he commits suicide'. ${ }^{72}$ Austrian botanist and local historian Dr Friedrich Morton (1890-1969) came to a different conclusion in his enthusiastic and thoughtful evaluation of the work, having found the portrayal of Sperl convincing. He opines that the state prosecutor's weakness brings about his demise, and he underlines Györki's poetic and acting skills, his knowledge of languages and his forces of fantasy in general. ${ }^{73}$

Sperl's character caught the imagination of reviewers most likely because they could identify with the erudite state prosecutor. Yet Wulffen shows over and over again how imposters intuitively and ruthlessly honed in on the wishes and desires of their victims, as well as their feelings of guilt; thus the victims frequently enabled the offences in the first place. This feature of the victim profile of impostors was discussed by American psychoanalyst and psychiatrist Phyllis Greenacre, who argued in 1958 that

in some of the most celebrated instances of imposture, it indeed appears that the fraud was successful only because many others as well as the perpetrator had a hunger to believe in the fraud, and that any success of such fraudulence depended in fact on strong social as well as individual factors and a special receptivity to the trickery. To this extent those on whom the fraudulence is imposed are not only victims but unconscious conspirators. ${ }^{74}$

Wulffen illustrates this propensity in all the characters of Der Mann mit den sieben Masken. However, he portrays the con man's impact on female victims as graver than that on the male victims involved: most male victims are defrauded of money that they give willingly in attempts to compensate for past failures, or for career advancement. Sometimes they lose wives, lovers and daughters to the ingenious trickster. Women, by contrast, bear a greater emotional cost: divorce, suicide, being committed 
to a mental asylum or becoming complicit to the extent of manslaughter and murder. Wulffen makes clear in other contexts that he considers women more vulnerable than men, due to the 'female fate' to love just one man (men in turn were perceived as "physiologically different, less favourably organised [polygamous]', than women). ${ }^{75}$ He promoted the increased participation of women in society, publicly supported the admission of female lay assessors (Schöffen) for juvenile courts, preferred female prison officers over their male counterparts. Nonetheless, Wulffen was convinced that women's only concept of honour and morality was defined by 'sexual honour' ('Geschlechtsehre'), their respectability, that is, pride in her virginity, and later in being a faithful wife. ${ }^{76}$ At the same time, he did not consider social factors, and held responsible the parent generation in their duty of care towards young women.

This stance towards women is best illustrated in Wulffen's description of the character Klarika in Der Mann mit den sieben Masken. Klarika is seduced by Györki as an under-aged girl and remains under his spell until the end of their lives. Wulffen's description of Klarika is based on qualities entirely different from those of Sperl, and is phrased in the language of sexual pathology. Klarika first met Györki and fell in love with him aged fifteen in Baden, where he was involved in an affair with Mrs Ferenczi. Klarika's seduction at an early age represents her downfall. Her love - as Wulffen writes about female criminals in his academic case compilation Der Sexualverbrecher - represents 'the absolute, sometimes slavish complaisance to the man of her choice [that] leads her on a criminal path'. ${ }^{77}$ In the novel, this is exemplified through Klarika's criminal negligence of a patient she is nursing, who dies because, yet again, Klarika pursues her lover and leaves behind a life she has built for herself. Other characteristics also portray her in a language of sexual pathology. She is unable to recognise him after she has broken away from him, and afterwards enters a kind of 'waking state' in which she leads a respectable life. Klarika certainly seems somnambulistic in a close-up through the eyes of Sperl when he interviews her for the court case, and after that in the meeting with Györki; then again as the nun who leaves behind her sick patient and departs with Györki for the USA; and finally, on her last journey back to European shores. Wulffen's vocabulary for the encounter with Sperl is distinct - his narrative voice describes Klarika speaking slowly and monotonously, hardly looking at Sperl, her facial expression 'faraway', and never calling Györki by his real name, but only by his false names. Overall, "she seemed to take this opportunity to live through the lost dream again'. ${ }^{78}$ Upon meeting Györki she is paralysed, unable to move, and begins shaking; her look becomes veiled. The description of this physical reaction does not offer insight into her feelings, just as readers do not gain direct insight into Györki's emotional life; however, Klarika's dependence is vividly portrayed.

Wulffen's multifaceted explorations of imposture pre-empt later psychoanalytic insights about con men, and more generally about 
narcissistic behaviour. He presents relevant case materials in a range of publications and case modalities, yet these do not so much represent different insights as reveal how Wulffen targeted both expert and lay audiences in his case compilations, expert case studies and case stories. The key difference between Wulffen's expert case study of Manolescu and his most famous case story of imposture lies in the factual specificity and formal register of the former, and in the general claims and entertaining descriptions of the latter. While the expert case study was based on discursive arguments and logic, the case story illustrated in detail how characters were made fools of, and how they suffered as a consequence, topics Wulffen was able to discuss only briefly in his expert case study.

The representation of a con man in his novel Der Mann mit den sieben Masken is notable as a detailed illustration of Wulffen's psychological insights, as well as his biological explanatory framework concerning imposture. While he holds a certain admiration for con men, and expresses pity for their victims, Wulffen outlines the real distinction between criminals and their victims through the powers of biology. For Wulffen, Klarika represents the "downright marked female fate, to love only one man, [which] became true for her in a tremendous and harrowing way'. ${ }^{79}$ Sperl and Klarika epitomise Wulffen's gendered criminal psychological theories: Sperl as the example of the guardian of the law who is fooled by his desire for knowledge; Klarika as the example of a prematurely sexually active teenager whose sex makes her vulnerable. This is what Sperl does not understand, and what causes or at least hastens Klarika's downfall. Tensions between psychological explanations of criminality and notions of biological determinism in Wulffen's thinking became more marked over time. During the Weimar period these tensions opened his work to critique from various factions.

\section{Female felons and the crisis of the expert case study}

If imposture was the favourite topic of Wulffen's exploration of criminality during the late Wilhelmine era, female felons became his subject of choice during the Weimar Republic. As established elsewhere in discussion of the Grete Beier case, Wulffen's concern with changing female gender roles and the perceived dangers were linked with societal change, and placed the stern democrat on an awkward footing with progressive forces in Weimar Germany. ${ }^{80}$ This argumentative shift seems somewhat surprising, since Wulffen's framework for understanding male criminality had always been more complex, and had developed greatly since his first explorations in Psychologie des Verbrechers (1908). He reworked this study for publication 1926, with the new title Kriminalpysychologie. Psychologie des Täters (Criminal Psychology. Psychology of the Perpetrator). In this version, Wulffen left behind the pre-war focus on physiology and biology; he had developed a new criminal psychology that none less than Bernhard 
Weiß, Vice President of the Berlin Police Force, described as 'the key work of contemporary criminal psychology ... an apex not only of German criminalistic literature, but of criminalistic world literature' ${ }^{81}$ The volume encompassed a range of new case studies as well as insights into a variety of crimes, from imposture to theft and murder; it included considerations of wider crime-related phenomena, such as affective states after a crime and false confessions.

With such rich materials and methodologies to hand, the reasons for Wulffen's comparatively simplistic exploration of female felons are more complex than have been perceived in scholarly discourse so far. They are an expression of a confluence of factors: an increasing 'nature-nurture' divide between psychiatry and criminal psychology on one side and psychoanalysis on the other - neither of which Wulffen found convincing; a perceived rise in criminality; his increasingly troubled relationship with the explicit nature of public discourse about sex; and, importantly, the decline of Wilhelmine notions of respectability and morality in a traumatised post-war society, which was tending to romanticise sexual crime. All these factors helped to undermine the standing of the case study genre as a site of academic discourse, and as a site of respectable and empirical discourse about sexuality.

Wulffen's increased interest in female criminality after 1919 was influenced by his stellar rise in the Weimar Republic, to the position of a chief public servant in the Saxon Ministry of Justice, and his election to the Saxon parliament as a member of the socially liberal German Democratic Party (DDP). As a member of the DDP he sat at the disintegrating centre of Germany's increasingly polarised political landscape. Like no other party, the DDP aimed to represent a balanced position on many questions of post-war life, and did so as a government party. From its foundation in 1919 to 1932 the DDP was nearly continuously part of Weimar coalition governments, although its influence declined steadily. ${ }^{82}$ In a climate of rapidly changing social attitudes and moral values, the DDP sought to represent the middle ground. It supported progressive social reform-oriented legislation, but also - to the great dissatisfaction of German left-wing writer Kurt Tucholsky - the 1926 Schund und Schmutz (filth and trash) paragraph, instating the first Weimar-era censorship, mainly aimed at the protection of youth. ${ }^{83}$

With his undiminished sense of mission when it came to legal reform, Wulffen throughout his career successfully identified new criminological trends. When crime statistics showed a spike in female criminality, he reacted with characteristic vigour and wrote the first and only booklength German specialist volume on the topic in the 1920s, titled Das Weib als Sexualverbrecherin (1923). This work has been widely quoted in studies of Weimar gender relations and criminality, either because of its perceived tendentious outlook, or because of the rich casuistry it provides. ${ }^{84}$ As in Wulffen's other case compilations, the case studies collected here offer examples for a range of discourses. They include contributions to the 
three argumentative strands that defined debate about female criminality in the new Republic. In the Weimar Republic gender difference helped to explain both why women committed fewer crimes overall, and the existence of specific 'female' felonies such as murder by poisoning, or procuring (prostitution) among female criminals. The rise of female criminality was more broadly explained by the perceived masculinisation of women that followed from the First World War and the post-war brutalisation of society - further explored in Chapter 5 of this volume. ${ }^{85}$

As when writing about imposture, Wulffen assumed the German people, including German academics and writers, to be naive in their understanding of female criminality; evidence for such naivety could be seen, for instance, in a new leniency in juries' sentencing of female offenders. ${ }^{86}$ Indeed, criminological fantasies in Weimar Germany predominantly portrayed women as victims rather than perpetrators. Wulffen challenged this bias in particular because the new Republic provided 'the weaker sex' with new rights and opportunities, but also with a range of 'temptations'. According to Wulffen, the lost war, revolution and female suffrage - which to him represented women's unconditional emancipation - created a materialistic ethos among male and female youth that diminished differences between the sexes, a view widely shared by twenty-first-century scholars of Weimar Germany. However, Wulffen insisted on the gender difference between men and women, and that young women, as exemplified in Klarika in Der Mann mit den sieben Masken, were more vulnerable than men. This position shows parallels with the stance of the DPP on Schmutz und Schund literature, a debate that, in Luke Springman's words, "provided a thoroughly structured sentimental archetype of youth threatened by decadent society' ${ }^{87}$ Such debates can be interpreted as evidence of cultural anxiety in the face of radical change, couched typically for the period in terms of concern for the next generation.

Wulffen most decisively expressed this sentiment in his introductory essay to the collection of expert case studies Irrwege des Eros (Aberrations of Eros) of 1928, a volume that showcases the downfall of fourteen female criminals. Because Wulffen perceived crimes to be the result of misdirected sexual urges, and Weimar's sexualisation was beyond the control of the law ('since too many old and young people live on such things'), in Irrwege des Eros he appealed to the intellectual and spiritual ideals of the previous generations as a guiding light. ${ }^{88}$ In the context of this moralistic plea Wulffen contended that mothers did not appreciate how vastly gender roles had changed, and that their daughters needed guidance, particularly since the relationship between mothers and daughters presented a lacuna in the German imagination - in fiction as well as in reality. ${ }^{89}$

While Irrwege des Eros parades its female criminals as a deterrent for its female readers, and appeals to mothers to bridge a generational divide that shaped the Weimar era, in Das Weib als Sexualverbrecherin Wulffen addressed his professional audience to consider - against the criminological 
fantasies of the time - the possibility of female felony. ${ }^{90} \mathrm{Wulffen}$ expresses the belief that his work will further the understanding of female criminality for science, judicial practice and the arts; that the casuistry would stand independently and be self-explanatory. ${ }^{91}$ The introduction to Das Weib als Sexualverbrecherin elaborates most succinctly Wulffen's theoretical stance. Firstly, Wulffen observes that a lack of systematic exploration of female sex offenders has created the need to showcase female criminality, since previous works in the field provide no or at least insufficient casuistry. ${ }^{92}$ Secondly, he stresses the criminal psychologist's assumption that criminality is innate to human existence and not solely a reflection of the social ills of society. At the same time, he rejects the experimental culture of knowledge that had begun to dominate German psychology, biological criminology and forensic psychiatry. Wulffen perceived this approach as remote from legal practice, confined to its psychiatric ivory tower. ${ }^{93}$ To Wulffen such a retreat from the case study genre also represented a move away from an empiricism that refused both a purely sociological framework and a purely biological framework for explaining female criminality.

At the same time - and seemingly in a contradictory manner - Wulffen reiterated the argument that heredity or degeneration contributed to female criminality. He did so to explain why a minority of women committed crimes in the first place, and thus to take a stance against an exclusively social constructionist approach that, in his view, furthered the sexualisation of society. The combination of these arguments shaped much of the reception of Das Weib als Sexualverbrecherin and caused considerable antagonism. Colleagues such as fellow sexologist Juliusburger backed a more liberal and emancipated view and, like other reformers, worked towards the normalisation of female sexuality. He had sympathetically reviewed many of Wulffen's works in the past, but now declared incomprehensible the argument that 'female criminality less than its male counterpart is caused by social conditions'. ${ }^{94}$ Similar critique was voiced behind the scenes. In 1931, just before Das Weib als Sexualverbrecherin was to be published in a third edition by HRW publishers, the editor formulated his critique along comparable lines. HRW had recently purchased the copyright for the series 'Encyklopädie der modernen Kriminalistik' ('Encyclopaedia of Modern Criminology') from Langenscheidt, the company that had published most of Wulffen's academic works. ${ }^{95}$ To update Das Weib als Sexualverbrecherin, the new editor suggested a range of changes, most importantly a revision of what he perceived to be the "at some points too pessimistic' view of women. ${ }^{96}$ In light of new publications on the topic, the publisher suggested adaptations and revisions on a range of issues (from female procuring to prostitution) and championed the 'modern' view of crime as solely explained by social factors. ${ }^{97}$

Such critique of Wulffen's perception of women coincided with a crisis in the book market and with a decline in sales numbers, as outlined elsewhere. ${ }^{98}$ As documented in his correspondence with his publishers, Wulffen found himself in a marketplace where book titles were used to 
'lure' readers, as were photographs and suggestive advertisements for sexological works. This only reinforced his view that 'our complete intellectual world has become impregnated [sic] by sexuality' and did nothing to ease his concerns about the vulnerability of women. ${ }^{99}$ Wulffen's struggle to retain agency over the presentation and wording of his own works becomes obvious in a number of ways. For instance, Julius Brüll, the publisher of Irrwege des Eros, suggested changing the title of the volume to the more titillating and ambiguous Erotische Verbrecherinnen (Erotic Female Felons); Wulffen refused. ${ }^{100}$ In preliminary discussions about a third edition of Das Weib als Sexualverbrecherin, HRW pushed Wulffen to include more of the graphic photographs that had undoubtedly attracted a wider readership. The publisher found the photographs duly submitted by Wulffen 'excellent', but argued that 'the number of images can easily be doubled without undermining the scientific character of the publication'. ${ }^{101}$ Emphasising that selling books had become 'a hundredfold harder in these hard times', HRW also suggested that Wulffen increase his publicity by launching articles in illustrated newspapers and high-circulation magazines, and by using 'lively and striking images' for advertising the book. ${ }^{102}$

Wulffen's dispute with HRW about images lasted over nine months, during which time he remained adamant about the academic respectability and appropriateness of the materials. He favoured images from official sources, such as the criminal museum in Hamburg or the police. ${ }^{103} \mathrm{HRW}$ highlighted a concern with sales numbers and suggested that images would also be much valued by the police and other readers with a professional interest in the material, but Wulffen remained unconvinced. ${ }^{104}$ When HRW pointed out to Wulffen that he had published a chapter in the sexological cultural studies series 'Die Erotik in der Photographie' ('The Erotics of Photography'), which had also produced a supplementary volume of photographs, Wulffen disputed having ever seen these images; this seems plausible, given the publishing history of the supplementary volume. ${ }^{105}$ He argued that "while recently sadistic-masochistic and fetishist images have become so common, this constitutes nonsense that we absolutely should not take part in'. ${ }^{106}$ Upholding his pre-war assumption about his different target audiences, he further suggested that while such images might have their place in an academic volume about erotic photography, and even in a literary or artistic context, they were of no relevance to a volume on sex crime, which would be concerned with reality and not staged masochistic and other scenarios. ${ }^{107}$

Libel presented another problem. In a later letter to HRW, Wulffen complained of market competition from books by non-academic authors. ${ }^{108}$ Specifically, Wulffen complained about Robert Heymann (1879-1946), film director and writer of popular fiction and popular cultural histories, whose volume Der Sexualverbrecher (The Sex Offender) was published in 1931 by Lykeion. ${ }^{109}$ Wulffen raised the issue of title copyright with his own publisher and a compromise was negotiated with Lykeion. New 
imprints of Heymann's book showed a title change to Das Verbrechen. Eine Sittengeschichte menschlicher Entartung (Crime. A History of Human Aberration) and those copies already printed received a paper jacket printed with the new title. ${ }^{110}$ The ambiguous sales strategy adopted by Lykeion represents an excellent example of the practices employed by many publishers in the Weimar Republic. Like other publishers of cultural studies, Lykeion stretched the boundaries of sexological respectability on the way to sexual modernity. Many new titles referenced sexological discourse; however, it was often difficult to identify whether they foregrounded academic or expert knowledge, represented a further popularisation or eroticisation of these discourses, or were merely a means to avoid censorship. For instance, Lykeion printed works of respected academic authors like literary historian Paul Englisch, as well as more provocative series such as Heymann's 'Sexuelle Hörigkeit. Sittengeschichte der Erotomanie' ('Sexual Enslavement. A History of Erotomania'), which included titillating titles such as Der masochistische Mann (Masochist Man) and Die hörige Frau (The Sexually Enslaved Woman), both published in 1931. ${ }^{111}$

This increasing willingness to explore sensationalist and erotic literature was partly due to economic necessity. The courts' inability to contain such publications was concurrent with the Weimar public's potent fascination with criminality. Such 'criminalistic fantasy' - a term recently revived by Todd Herzog but first coined in 1927 by Bernhard Weiß of the Berlin police - threatened Wulffen's reform project and the legitimacy of his reliance on the case study genre. The new ubiquitous presence and commercialisation of confessional and autobiographical writing during the Weimar period exerted an influence on the case study genre, challenging traditional boundaries between academic discourse and popular fiction. Where Wulffen had carefully crafted a space for his expert case studies and case stories, new autobiographical case studies began to appear. Such personal narratives were infused with the respectable language of sexological or psychoanalytic discourse and also romanticised criminal acts. As Wulffen all too clearly realised, this 'lay' use of specialist terminology affected the popularisation and diffusion of the meaning of such discourses.

There is no better way to portray the ambiguous shift in sexual modernity from the respectable norm to the agency of the 'perverse' individual than through Wulffen's exchange with Edith Cadivec. Cadivec was a private language teacher, a convicted paedophile and a writer of erotic literature. In 1924 she was convicted of having sadistically abused her protégé and four pupils in her care; the court case revealed that a range of respectable Viennese burghers had paid to watch this punishment for their own sexual gratification. As a consequence, Cadivec was sentenced to seven years in jail - of which she served less than four years - while just two of the co-defendants were placed on probation. Austrian feuilletonist and writer Alfred Polgar criticised the double standards of this court ruling, but wrote that Cadivec 'was not really entitled to claim any sympathies'. ${ }^{112}$ 
On 2 June 1932, Cadivec wrote a letter to Wulffen, a document that has not been studied before. In the letter she demanded an apology from Wulffen for purportedly denying the truthfulness of her statements, while having previously complimented her on her willingness to confess. By way of defending her position to Wulffen, Cadivec curtly argued, "knowledge deceives and betrays. Truth is what we experience."113 From Wulffen's perspective, Cadivec's attempt at agency was ill conceived. His 1928 Irrwege des Eros, produced by the publishing house Avalun, contains an expert case study of Cadivec as a self-proclaimed sadist. It must have been troubling to Wulffen that, after publication of Irrwege des Eros, his publisher, Julius Brüll, the owner of Avalun, approached Cadivec and published her volume Bekenntnisse und Erlebnisse (Confessions and Experiences) in 1931. Furthermore, Brüll used Wulffen's expert case study in an endorsement for Cadivec's autobiography. ${ }^{114}$ Wulffen was not impressed, and when Cadivec's book was banned he agreed with the verdict of the court, although the volume was offered only as a subscription volume for libraries and academics; he refused to support Brüll in overturning the censorship decision. ${ }^{115}$ This refusal was in line with the court and with the position of the DDP. It represented a small and futile attempt to suppress Cadivec's writings, which soon became classics of sadistic and paedophile literature. ${ }^{116}$

In the shape of a pseudo-psychoanalytic case study, Cadivec explained her life story. Her confessions in Bekenntnisse und Erlebnisse include erotic and pornographic passages. The book's paedophile content contrasts starkly with the explanatory psychoanalytic framework and language that Cadivec uses to account for herself. ${ }^{117}$ She referenced psychiatric, but mostly psychoanalytic discourse, a fact that had been noted by the forensic expert in his report for her trial. ${ }^{118}$ One of Cadivec's co-defendants, lawyer Alphons Peter Kuh-Chrobak, underwent psychoanalytic treatment with Ludwig Jekels, but Cadivec did not submit herself to psychoanalysis. ${ }^{119}$ This might have been due to financial constraints, but her intense and eclectic engagement with psychoanalytic discourse meant that Cadivecas stated in the psychiatric report at her trial - "with the help of auto- and other [psychoanalytic] suggestions, had been able to develop a perception of her actions that did not contradict morality'. ${ }^{120}$ That is, Cadivec adapted the narrative of authentic truth that underlies psychoanalysis, but, like a con artist, she was unable to take any responsibility for her actions. Her writings showed no compassion for her daughter, her protégé or the pupils whom the court found she had sadistically abused. ${ }^{121}$ Rather, Cadivec resolutely sought new court hearings: following her conviction in September 1924, she applied for new hearings of her case eleven times (the last time in 1953), always in lengthy and well formulated submissions; all her applications were rejected.

No doubt Wulffen was not surprised by this development, nor by Cadivec's need to write. The parallels to Manolescu are telling, although Wulffen never spelled them out. As Wulffen underlines in his expert 
case study of the latter, Manolescu's writing career began after he was prevented from thieving 'in reality', due to the loss of his arm. ${ }^{122}$ Cadivec commenced writing when imprisoned, and due to the loss of her reputation as a teacher. Wulffen was also familiar with the criminalistic fantasies of convicted criminals that centred on institutions of authority and their representatives. Hence Manolescu's day-dream of selling his skull to Lombroso, or the second volume of Manolescu's autobiography, which contained a plea against psychiatric containment; hence those con artists who involved Wulffen in their criminal fantasies. Two undated newspaper clippings in the archive of Wulffen's papers reveal that farmer Hermann Friedrich Karl Thürnau had posed as a baron and one of his false names was Erich von Wulffen. In another example, when accused of fraud, Margaret Engel alleged Wulffen to have wooed her, and wrote to abdicated Emperor Wilhelm II to request that he convince Wulffen to divorce his wife. After Engel was acquitted on grounds of diminished responsibility, she defrauded a range of businesses, including first-class hotels, arguing that the Saxon courts would pay the costs because Wulffen had falsely accused her. ${ }^{123}$

Cadivec's publications were, however, of a different nature. Wulffen saw her use of a sexualised language - in her Bekenntnisse and Erlebnisse and in her letter - as symptomatic of post-war German and Austrian society in general. Cadivec's use of case study fragments in her confessions must have deeply concerned him. This contributed to a remarkable development: the former supporter of psychoanalysis now took the view that psychoanalysis, far from serving as a cure, was furthering the sexualisation of society. Presumably, Wulffen's re-assessment of psychoanalysis was based at least in part on the Cadivec case. In an undated four-page manuscript titled 'Siegmund [sic] Freud' Wulffen elaborates:

Especially the sexual lure that surrounds the whole theory; the assertion that all our feelings and thoughts and every interpretation of our state and behaviour has a sexual context holds an extraordinary attraction for human beings in general, and especially at this time. That it represents a crass materialism is hardly noticed. Existence and life become eroticised in the extreme, sexualised in a time where all other stimulants fail. The over-eroticisation and sexualisation from which the present suffers are due, in the main, to the Freudian teachings. ${ }^{124}$

In turning his back on psychoanalysis, Wulffen also distanced himself from the field of knowledge that, after the 1920s, retained the strongest connection to the case study genre. Originally, in the early twentieth century, Wulffen had responded enthusiastically to Freud's theories. In a 1910 review of Der Sexualverbrecher, Juliusburger pointed out that Wulffen's works were based on Freud. ${ }^{125}$ Indeed, Wulffen accepted the fundamental impact of sexuality on human nature that Freud's theories proposed. This led to the subsequent unusual classification of a wide range of criminal offences as sex crimes (from theft to sex murder). Wulffen's 
embrace of psychoanalytic theories becomes very evident in his critique of William Shakespeare's Hamlet, published in 1913, a work that argues from sexological and psychoanalytic perspectives. ${ }^{126}$ Nevertheless, with the benefit of hindsight, in a review of 1932 Juliusburger names Wulffen among a large number of criminologists who had come to the conclusion that the "psychoanalytic turn' from 1913-14 was no longer scientifically responsible. ${ }^{127}$ The mounting dissatisfaction with psychoanalysis also resulted from attempts by psychoanalysts like Abraham to establish their hold in the legal world, and their ignorance of Wulffen's writings. ${ }^{128}$ While Wulffen granted Freud a consistency in methodology, he pointed to the danger of manipulation in the psychoanalytic process: free association permits mistakes, lack of discrimination, self-suggestion and deception, making patients susceptible to 'all kinds of interpretations'. For Wulffen this disqualified psychoanalytic methods from being used in court, either during interrogation or for witness statements. ${ }^{129}$

It is also possible that Wulffen held the psychoanalytic method of free association responsible for the highly problematic tone and content of Bekenntnisse und Erlebnisse. Cadivec's use of free association created a work of erotic literature in which conventional distinctions between reality and fantasy collapsed. (A psychoanalytic interpretation of Cadivec's case would have rejected her interpretation as an expression of narcissism.) In all, Wulffen was well aware of the attraction that Cadivec held for her readers. In 1931, a certain Friedrich Harth wrote to Wulffen seeking direct contact with Cadivec. Harth had read Wulffen's expert account of Cadivec in Irrwege des Eros, which quoted passages of Cadivec's self-description. After reading these passages Harth was 'moved and galvanised'; Wulffen's commentary did not have this effect. Harth hoped to read everything written by Cadivec, to help him solve his "puzzle of his soul'. ${ }^{130}$ Wulffen's account could not compete with the fascination exercised by Cadivec's writing.

Wulffen's expert and pedagogical use of the case study genre had insisted on an authoritative distinction between criminal fantasy and legal reality that did not prove helpful for Harth. In other words, Harth was drawn to the particular blend of reality and fantasy that Herzog describes as characteristic of Weimar's criminalistic fantasies. Harth's reading of Cadivec might point to an underlying trauma, his attraction to Cadivec based on similar desires that represented an attempt to resolve or repeat this trauma. Such ambiguity lies at the heart of the making of German sexual modernity, and in the context of criminality it raised serious ethical questions.

Whether expressed in connection with Cadivec's case conviction and censorship, or more generally in his call for chastity among young women, Wulffen's solution to the question of female criminality seems a mixture of appropriate, old-fashioned and unrealistic. Wulffen interpreted the increasingly noticeable collapse between the respectable language of sexology and the sexualisation of language as a sign of the brutalisation 
of post-war society. The same trends and shifts can also be interpreted as a consequence of the onset of sexual modernity - a sexual modernity to which Wulffen had made a significant contribution, notably through his popularisation of several case modalities. Sexual modernity now represented a crisis for Wulffen's reformist and pedagogical project. He distanced himself from psychiatry, with its new experimental ethos and new scientific style of writing. He blamed psychoanalysis as the cause of the sexualisation of language. These attitudes contained, furthermore, a refusal to reflect on his own role in the dissemination of sexological knowledge. After all, over a period of almost three decades Wulffen had skilfully fostered multiple reading publics for case study compilations, expert case studies and case stories. The recent and more democratic uptake of the case study genre that Wulffen witnessed with trepidation destabilised the genre's respectability. In a certain way this made the genre unviable for academic discourse; having helped to make manifest the German populace's embrace of criminalistic and sexual fantasies, the case study was revealed as deeply subjective. Wulffen's experience, then, was that of the modern mandarin more generally. The liberal hub of Weimar Germany crumbled, and Wulffen's reservations and anxieties concerning the changing respectability of the case study genre, the role of women and the romanticisation of criminality exemplify challenges faced by the old liberal elite in cleaving to their notions of propriety and related ethical standards.

\section{Notes}

1 Sächsische Landesbibliothek - Staats- und Universitätsbibliothek, Dresden (hereafter SLUB), Nachlass des Schriftstellers und Kriminalisten Min.-Direktor Dr Erich Wulffen (1862-1936): Signatur: Mscr. Dres. App. 1832, 102 (5), 'Deutsche Kriminalisten', Berliner Illustrirte Zeitung, 17 (1927), pp. 700-1.

2 Reiner Grundmann and Nico Stehr, Experts: The Knowledge and Power of Expertise (New York: Routledge, 2011), pp. 8-13.

3 Fritz Ringer, The Decline of the German Mandarins: The German Academic Community, 1890-1933 (Hanover: University Press of New England, 1969), p. 248.

4 For the liberal leanings of criminal psychologists see Richard F. Wetzell, Inventing the Criminal: A History of German Criminology, 1880-1945 (Chapel Hill: University of North Carolina Press, 2000), pp. 168-74; Wulffen is explicitly mentioned in Jason Crouthamel, 'Male Sexuality and Psychological Trauma: Soldiers and Sexual Disorder in World War I and Weimar Germany', Journal of the History of Sexuality, 17:1 (2008), pp. 60-84; Andrew Lees, Cities, Sin, and Social Reform in Imperial Germany (Ann Arbor: University of Michigan Press, 2002), pp. 169-70, pp. 181-4.

5 Crouthamel, 'Male Sexuality', p. 75.

6 Monika Frommel, 'Internationale Reformbewegung zwischen 1880 und 1920', in Jörg Schönert (ed.), Erzählte Kriminalität. Zur Typologie und Funktion von narrativen Darstellungen in Strafrechtspflege, Publizistik und Literatur zwischen 1770 und 1920 (Tübingen: Niemeyer, 1991), pp. 447-96, p. 489; on Wulffen's view on prostitution see Peter Becker, 'Weak Bodies? Prostitutes and the Role of 
Gender in the Criminological Writings of 19th-Century German Detectives and Magistrates', Crime, History and Societies, 3:1 (1999), pp. 45-70, pp. 60-1.

7 Erich Wulffen, Psychologie des Verbrechers. Ein Handbuch für Juristen, Ärzte, Pädagogen und Gebildete aller Stände (Groß-Lichterfelde Ost: Paul Langenscheidt, 1908), pp. 318-49; Erich Wulffen, Kriminalpsychologie. Psychologie des Täters. Ein Handbuch für Juristen, Justiz-, Verwaltungs- und Polizeibeamte, Ärzte, Pädagogen und Gebildete aller Stände (Berlin: Paul Langenscheidt, 1926), pp. 133-6. Even Wulffen's benevolent obituary of Lombroso contains a critical discussion of some of the latter's insights: SLUB, Nachlass des Schriftstellers und Kriminalisten Min.-Direktor Dr Erich Wulffen (1862-1936): Signatur: Mscr. Dres. App. 1832, 1383, Erich Wulffen, 'Cesare Lombrosos Lehre vom Verbrecher', Nord Süd, circa 1909 , n.p.

8 '[D]e[n] geniale[n] Fortsetzer der Tat Lombrosos und [er] ist der berufene Reformator des morschen, dem Untergange reifen alten Strafsystems.' Otto Juliusburger, 'Der Sexualverbrecher', Die neue Generation, 14:7 (1910), pp. 259-64, p. 264.

9 SLUB, Nachlass des Schriftstellers und Kriminalisten Min.-Direktor Dr Erich Wulffen (1862-1936): Signatur: Mscr. Dres. App. 1832, 81. 'Im Gegensatz zu Lombrosos Theorie vom geborenen Verbrecher verficht Wulffen die Anschauung, daß in jedem Menschen Kriminalität latent vorhanden sei': 'Erich Wulffen 70 Jahre alt', Dresdner Neueste Nachrichten, 2 October 1932, p. 5.

10 Wetzell, Inventing the Criminal, pp. 125-78.

11 Udi E. Greenberg, 'Criminalization. Carl Schmitt and Walter Benjamin's Concept of Criminal Politics', Journal of European Studies, 39:3 (2009), pp. 305-19, p. 315. On biologisation, see Wetzell, Inventing the Criminal, pp. 125-78; on the depiction of crime in popular culture, see, for example, Maria Tatar, Lustmord: Sexual Murder in Weimar Germany (Princeton: Princeton University Press, 1995).

12 Todd Herzog, 'Crime Stories: Criminal, Society, and the Modernist Case History', Representations, 80 (2002), pp. 34-61, p. 35.

13 Daniel Siemens, 'Explaining Crime. Berlin Newspapers and the Construction of the Criminal in Weimar Germany', Journal of European Studies, 39:3 (2009), pp. $336-52$, p. 337.

14 See Greenberg, 'Criminalization'.

15 Todd Herzog, Crime Stories: Criminalistic Fantasy and the Culture of Crisis in Weimar Germany (New York: Berghahn, 2009), p. 4.

16 Harry Oosterhuis, 'Sexual Modernity in the Works of Richard von Krafft-Ebing and Albert Moll', Medical History, 56:2 (2012), pp. 133-55.

17 SLUB, Nachlass des Schriftstellers und Kriminalisten Min.-Direktor Dr Erich Wulffen (1862-1936): Signatur: Mscr. Dres. App. 1832, 1477.

18 C. G. Jung, "Besprechung von Erich Wulffen "Der Sexualverbrecher", Jahrbuch für psychoanalytische und psychopathologische Forschungen, 2:2 (1910), p. 747.

19 Arthur J. Todd, 'Review of Der Entwurf eines deutschen Strafgesetzbuches und Die Postulate der Internationalen Kriminalistischen Vereinigung und die Beschlüsse zweier Strafrechtskommissionen', Journal of the American Institute for Criminal Law and Criminology, 5 (1914-15), pp. 789-95, p. 790. A comprehensive history of German penal reform is yet to be written; however, Wulffen's dedicated involvement in the reform process is well documented in his writings. The following references discuss the history of the International Criminological Association in some detail: Frommel, 'Internationale Reformbewegung', pp. 447-96; Elisabeth Bellmann, Die Internationale Kriminalistische Vereinigung, 1889-1933 (Frankfurt: Lang, 1994); Sylvia Kesper-Biermann, "Wissenschaftlicher Ideenaustausch und "kriminalpolitische Propaganda". Die Internationale Kriminalistische Vereinigung (1889-1937) und der Strafvollzug', in Desiree Schauz and Sabine Freitag (eds), Verbrecher im Visier der Experten: Kriminalpolitik zwischen Wissenschaft und Praxis im 19. und frühen 20. Jahrhundert (Stuttgart: Steiner, 2007), pp. 79-97. 
20 Erich Wulffen, Frau Justitias Walpurgisnacht. Roman (Berlin: Duncker, 1913). (Roman means 'novel' and was often used as a subtitle at the time.) In the Weimar era some newspaper articles would later claim that publication of this novel triggered the transfer of Wulffen from Dresden to Zwickau for disciplinary reasons. Since work records for Wulffen are lost, it is possible only to speculate whether their content alone contained sufficient fuel for professional conflict, or whether Wulffen's 'exile' was due to his novel's story of love and secret engagement between the young State Prosecutor Wartenberg, and the foster daughter of a judicial great. Even if Wulffen did not court the foster daughter of his teacher at university, the eminent scholar Karl Binding, it can be assumed that the novel was understood as an attack on his former professor, who retired in the same year as the novel was published. Moreover, Walpurgisnacht may have upset certain influential members of the legal profession, as did Wulffen's critique of the functioning of the court.

21 SLUB, Nachlass des Schriftstellers und Kriminalisten Min.-Direktor Dr Erich Wulffen (1862-1936): Signatur: Mscr. Dres. App. 1832, 1330, Erich Wulffen, 'Mein Umweg über die Dichter', circa 1932.

22 Wulffen, Walpurgisnacht, pp. 34-5; Wulffen, 'Mein Umweg über die Dichter'; Hugo Dingeldey, 'Erich Wulffen', in Alexander Baumgarten and Hugo Dingeldey (eds), Erich Wulffen. Festschrift zu seinem siebzigsten Geburtstag (Berlin: HRW, 1932), pp. 12-40, p. 13.

23 '[M]it einem vollen warmen Herzen an dieses ihm unbekannte Studium'; 'es dabei auf das Herz gar nicht ankommen sollte'. Wulffen, Walpurgisnacht, p. 39.

24 'Jetzt hörte er, daß er keine Ahnung von juristischer Schreibweise hatte. Aus der Korrektur des Amtsrichters sah er, worauf es ankam. Er hatte das Gefühlsmässige und Lebendige in dem kriminellen Vorgang betont. Das sollte nicht sein.' Wulffen, Walpurgisnacht, p. 41.

25 Wulffen, 'Mein Umweg über die Dichter'.

26 Wulffen, 'Mein Umweg über die Dichter'.

27 'Innenleben und Charakter, Verbrechensmotive und Umwelt des Täters.' Wulffen, 'Mein Umweg über die Dichter'.

28 'Schulbeispiele der kriminalpsychologischen Analyse.' Wulffen, 'Mein Umweg über die Dichter'.

29 Herewith a chronological listing of Wulffen's writing and lecturing on Goethe and Schiller: Kriminalpsychologie und Psychopathologie in Schillers Räubern (Halle: Marhold, 1907) (reprinted with a biography, comments and reviews through editor Jürgen Seul, Berlin: BWV, 2007); SLUB, Nachlass des Schriftstellers und Kriminalisten Min.-Direktor Dr Erich Wulffen (1862-1936): Signatur: Mscr. Dres. App. 1832, 1478, 'Aus Schillers tiefster Seele (im Lichte einer neuen Zeit)' announcement of a lecture in Zwickau on 29 January 1919; SLUB, Nachlass des Schriftstellers und Kriminalisten Min.-Direktor Dr Erich Wulffen (1862-1936): Signatur: Mscr. Dres. App. 1832, 1478, 'Kriminalpsychologie bei Schiller und Goethe', lecture delivered 1912-13; SLUB, Nachlass des Schriftstellers und Kriminalisten Min.-Direktor Dr Erich Wulffen (1862-1936): Signatur: Mscr. Dres. App. 1832, 1325, 'Ein hygienischer Ausspruch Schillers', radio presentation from 1931; 'Bekanntes und Unbekanntes über Goethe als Kriminalisten', in Volker Wahl (ed.), 'Das Kind in meinem Leib': Sittlichkeitsdelikte und Kindsmord in Sachsen-Weimar-Eisenach unter Carl August; eine Quellenedition; 1779-1786 (Weimar: Böhlau, 2004), pp. 232-327; SLUB, Nachlass des Schriftstellers und Kriminalisten Min.-Direktor Dr Erich Wulffen (1862-1936): Signatur: Mscr. Dres. App. 1832, 1377, 'Kriminalpsychologie in Goethes Iphigenie auf Tauris', undated.

30 '[S]ein[em] Essen, sein[er] Arbeit und sein[er] Ordnung.' Erich Wulffen, 'Ein kriminalpsychologisches Experiment', Monatsschrift für Kriminalpsychologie und Strafreform, 2 (1905), pp. 734-8, p. 735. 
31 'Veranlagung, Erziehung und Lebensschicksale haben ihn zu dem gemacht, was er ist und zu bleiben hat. Gegenüber diesen Schicksalsschwestern gibt es kein Entrinnen. Willensschwäche ist sein beschieden Teil, wie andere Menschen an organischen Schwächen leiden. Er kann nicht anders. Gott helfe ihm!' Wulffen, 'Ein kriminalpsychologisches Experiment', p. 730.

32 Silviana Galassi, Kriminologie im Deutschen Kaiserreich. Geschichte einer gebrochenen Verwissenschaftlichung (Stuttgart: Franz Steiner, 2004), p. 424.

33 Benjamin Carter Hett, Death in the Tiergarten: Murder and Criminal Justice in the Kaiser's Berlin (Cambridge: Harvard University Press, 2004), pp. 26-7.

34 Richard F. Wetzell, 'Psychiatry and Criminal Justice in Modern Germany, 1880-1933', Journal of European Studies, 39 (2009), pp. 270-89, p. 285.

35 Erich Wulffen, "Gerhart Hauptmann's "Rose Bernd" vom kriminalist. Standpunkte', Juristisch-psychiatrische Grenzfragen. Zwanglose Abhandlungen, 4:3 (1906), pp. 13-23, pp. 20-2. For his analysis Wulffen took inspiration from Josef Kohler (1849-1919), another jurist, and also a poet and cultural critic, whose works analysed legal questions raised in the work of William Shakespeare. Compare Josef Kohler, Shakespeare vor dem Forum der Jurisprudenz (Würzburg: Stahel, 1883).

36 '[I]nsbesondere vor dem Strafrichter bislang, wenn überhaupt, weit unter Gebühr gewürdigt wurden. Und sie verbreitet Licht in Abgründen von Verbrecherseelen, die bis heut weiteren Kreisen dunkel und unbegreiflich erscheinen.' Dr Glaser, 'Der Sexualverbrecher von E. Wulffen', Geschlecht und Gesellschaft, 5:9 (1910), pp. 415-24, p. 416.

37 Volkmar Sigusch, 'Erich Wulffen', in Volkmar Sigusch and Günter Grau (eds), Personenlexikon der Sexualforschung (Frankfurt: Campus, 2009), pp. 783-8, p. 784; Sace Elder, Murder Scenes: Normality, Deviance, and Criminal Violence in Weimar Berlin (Ann Arbor: University of Michigan Press, 2010), p. 25.

38 Galassi, Kriminologie im Deutschen Kaiserreich, pp. 424-6.

39 The following are all relevant reviews, sourced as clippings at SLUB, Nachlass des Schriftstellers und Kriminalisten Min.-Direktor Dr Erich Wulffen (1862-1936): Signatur: Mscr. Dres. App. 1832, 1477: 'Ein Buch vom Kinde. Erich Wulffen: Das Kind, sein Wesen und seine Entartung', Vossische Zeitung, 4 July 1914, n.p.; 'Literaturübersicht', Gerichtliche und Militärmedizin (no further reference details available). A number of reviews underline the value of Wulffen's books as reference works: Dr A. Weingart, 'Psychologie des Verbrechers', Deutsche Juristen-Zeitung, 14 (1909), p. 612; Heinrich Rustige, 'Psychologie des Verbrechers', Die Hilfe, 27 December 1908, n.p.; 'Literaturübersicht [on Sexualverbrecher]', Gerichtliche und Militärmedizin (no further reference details available); Willy Helpbach, 'Sexualverbrechen', Frankfurter Zeitung, 19 March 1910, n.p.; [on Das Kind, sein Wesen, seine Entartung und seine Erziehung], Vossische Zeitung, 4 July 1914, n.p.; Max Marcuse, [on Weib als Sexualverbrecherin], Zeitschrift für Sexualwissenschaft, 19:8 (1932), n.p.

40 Ludwik Fleck, 'Some Specific Features of the Medical Way of Thinking (1927)', in Robert S. Cohen and Thomas Schnelle (eds), Cognition and Fact: Materials on Ludwik Fleck (Dordrecht: Springer Netherlands, 1986), pp. 39-46, p. 39.

41 'Untersuchungspersonen [können] niemals der Vollmann oder das Vollweib [sein], sondern nach biologischer Erkenntis immer Personen mit einem mehr oder minder großen Einschlage der entgegengesetzten Geschlechtlichkeit.' Erich Wulffen, Das Weib als Sexualverbrecherin. Ein Handbuch für Juristen, Polizei- und Strafvollzugsbeamte, Ärzte und Laienrichter (Berlin: Paul Langenscheidt, 1923), p. 6.

42 Hett, Death in the Tiergarten, pp. 3-4; Birgit Lang, 'Influencing Public Knowledge: Erich Wulffen and the Criminal Case of Grete Beier', in Joy Damousi, Birgit Lang and Katie Sutton (eds), Case Studies and the Dissemination of Knowledge (New York: Routledge, 2015), pp. 49-65, pp. 50-2.

43 Gert Üding and Bernd Steinbrink, Grundriss der Rhetorik. Geschichte-TechnikMethode (Stuttgart: Metzler, 2011), pp. 278-83. 
44 Wulffen, Psychologie des Verbrechers, p. 263.

45 Lang, 'Influencing Public Knowledge', 50-1.

46 Georges Manolescu, Ein Fürst der Diebe. Memoiren (Groß-Lichterfelde Ost: Paul Langenscheidt, 1905); Georges Manolescu, Gescheitert. Aus dem Seelenleben eines Verbrechers (Groß-Lichterfelde Ost: Paul Langenscheidt, 1907); Erich Wulffen, Manolescu und seine Memoiren. Kriminalpsychologische Studie (Groß-Lichterfelde Ost: Paul Langenscheidt, 1907).

47 Wulffen, Psychologie des Verbrechers, pp. 317-18.

48 Matt Houlbrook, "Commodifying the Self Within: Ghosts, Libels, and the Crook Life Story in Interwar Britain', Journal of Modern History, 85:2 (2013), pp. 321-63, pp. 331, 335.

49 On the publisher's additional strategies for counteracting such tendencies see Birgit Lang 'Verbrecher im Fokus. Zur Zirkulation verbrecherischer und kriminalpsychologischer Fallgeschichten um 1900', in Wolfgang Hackl, Kalina Kupcyznska and Wolfgang Wiesmüller (eds), Sprache, Literatur, Erkenntnis (Vienna: Praesens, 2014), pp. 301-13.

50 Paul Lindau was a well known German writer whose crime writings represented only one strand of his creative output. His largest contribution to crime literature was his volume Interessante Fälle. Criminalprocesse aus neuester Zeit (Breslau: Schottlaender, 1888). Hans Hyan was a German cabarettist, writer and crime reporter who wrote over thirty crime-related novels in the first third of the twentieth century. Paul Schlesinger was the best-known crime reporter of the Weimar Republic.

51 Wulffen, Manolescu, p. 7.

52 Wulffen, Manolescu, p. 110.

53 ' $[\mathrm{I}] \mathrm{n}$ Wirklichkeit ... noch interessanter und ... von tieferer Bedeutung, als ihn die Memoiren geben.' Wulffen, Manolescu, p. 9.

54 For example, Wulffen reconstructs from the police files that Manolescu told his wife he was innocent when he had already confessed to the police. Wulffen, Manolescu, p. 51. Wulffen also identifies a range of omissions in the memoirs and corrects Manolescu's distortions of events. For instance, the latter underlines in his memoirs his physical resistance to the police, while in fact he was noted to have behaved very cooperatively. Wulffen, Manolescu, p. 49.

55 '[I]nstinktiven Naturwüchsigkeit.' Wulffen, Manolescu, p. 19.

56 Helene Deutsch, 'The Impostor: Contribution to Ego Psychology of a Type of Psychopath [reprint from 1955]', Psychoanalytic Quarterly, 80: 4 (2011), pp. 1005-24, pp. 1014-15.

57 See particularly Wulffen's analysis of Manolescu's family relations: Wulffen, Manolescu, pp. 38-55.

58 Sigmund Freud, 'Der Familienroman der Neurotiker (1909)', in Sigmund Freud, Gesammelte Werke, chronologisch geordnet, ed. Anna Freud, in collaboration with M. Bonaparte, E. Bibring, W. Hoffer, E. Kris and O. Isakower, vol. VII (London: Imago, 1952), pp. 227-31; Sigmund Freud, 'Family Romances', in The Standard Edition of the Complete Psychological Works of Sigmund Freud, ed. James Strachey, with Anna Freud, Alix Strachey and Alan Tyson, vol. IX (London: Hogarth Press and Institute for Psychoanalysis, 1959), pp. 235-42; Phyllis Greenacre, 'The Impostor', Psychoanalytic Quarterly, 27 (1958), pp. 359-82, p. 362.

59 Karl Abraham, 'Die Geschichte eines Hochstaplers im Lichte psychoanalytischer Erkenntnis', Imago. Zeitschrift für Anwendung der Psychoanalyse auf die Geisteswissenschaften, 9:4 (1925), pp. 355-70, p. 368; Karl Abraham, 'The History of an Impostor in the Light of Psychoanalytical Knowledge', Psychoanalytic Quarterly, 4 (1935), pp. 570-87.

60 Hermann Nunberg and Ernst Federn (eds), Protokolle der Wiener Psychoanalytischen Vereinigung. Band II (1908-1910) (Gießen: Psychosozial-Verlag, 2008), p. 67. This affinity was also noted by other reviewers, such as Alfred Adler, 
who was about to be ousted as President of the Vienna Psychoanalytic Society. The protocols of the Society from 9 December 1908 further reveal the awareness of psychoanalysts of Wulffen's work, and note that, in the description of a legal case, Wulffen used psychoanalytic 'nomenclature'. Abraham's premature death in 1925 was conceived by Freud's biographer and fellow psychoanalyst Ernest Jones as 'the most cruel and severe [blow to the science of psychoanalysis]' before the rise of National Socialism. Ernest Jones, 'Introductory Memoir', in Selected Papers of Karl Abraham, M.D., trans. Douglas Bryan and Alix Strachey (London: Hogarth Press, 1927), pp. 9-41, p. 9.

61 Ernest Jones, 'Introductory Memoir', in Ernest Jones, Selected Papers of Karl Abraham, trans. Douglas Bryan and Alix Strachey (London: Hogarth Press, 1927), pp. 9-41, p. 9.

62 ' $[\mathrm{I}] \mathrm{m}$ psychologischen Sinne vollkommene Erfüllung einer infantilen Wunschsituation.' Abraham, 'Geschichte eines Hochstaplers', p. 368; Abraham, 'History of an Impostor', p. 584.

63 'Empfindung [bleibt] lediglich ein Phantom und [nimmt] gar keinen realen, praktischen, auf das Wohl der Tochter gerichteten Inhalt an.' Wulffen, Manolescu, p. 45 .

64 '[Quälte] erst die Seinen, dann weinte er darüber wie ein Kind.' Wulffen, Manolescu, p. 52.

65 "[W]ir die hereditäre Belastung, die "Degeneration" in ihrer Bedeutung für das Entstehen dissozialer und krimineller Antriebe nicht überschätzen sollen.' Abraham, 'Geschichte eines Hochstaplers', p. 368.

66 Abraham, 'Geschichte eines Hochstaplers', pp. xxx and 370.

67 Die Traumtänzerin: Ein Roman (Berlin: Duncker, 1914); Vorgelesen, genehmigt! Roman (Berlin: Duncker, 1915); Die Kraft des Michael Argobast, Roman (Dresden: Reißner, 1917); Der Mann mit den sieben Masken, Roman (Dresden: Reißner, 1917); Das Haus ohne Fenster, Roman (Berlin: Duncker, 1919); Die geschlossene Kette: Roman (Berlin: Mosse, 1919); Der blaue Diamant: Roman (Leipzig: Leipziger Zeitungsverlag Dr Wolfgang Huck, 1919). Other fictional works from this period are: Deutsche Renaissance: Roman (Dresden: Reißner, 1917) and Die Frauen von Loburg, Roman (Berlin: Uhlmann, 1921).

68 SLUB, Nachlass des Schriftstellers und Kriminalisten Min.-Direktor Dr Erich Wulffen (1862-1936): Signatur: Mscr. Dres. App. 1832, 102(3), Der Weltspiegel. Illustr. Halb-Wochenschrift des Berliner Tageblattes, 2 November 1916, p. 3.

69 SLUB, Nachlass des Schriftstellers und Kriminalisten Min.-Direktor Dr Erich Wulffen (1862-1936): Signatur: Mscr. Dres. App. 1832, 1478. 'Der Mann mit den sieben Masken unser neuer Roman', Münchnen-Augsburger Abendzeitung, 23 September 1917.

70 Wulffen composed a less successful drama titled Immakulata, fictionalising the story of Manolescu's first marriage. Wulffen also tried a dramatisation for the stage under the title Mehr als Proteus. This version, however, remained unfinished. See SLUB, Nachlass des Schriftstellers und Kriminalisten Min.-Direktor Dr Erich Wulffen (1862-1936): Signatur: Mscr. Dres. App. 1832, 1044.

71 'Über den literarischen Wert seines Werks ein Urteil abzugeben, fühle ich mich nicht berufen. Vom Standpunkt der Kriminalpsychologie aber haben wir es hier zweifelsohne mit einem außerordentlich lehrreichen Buche zu tun, das zum mindesten auch eine fesselnde und gute Unterhaltungslektüre bildet. Der Kenner der Kriminal-Geschichte wird übrigens das Urmaterial, aus dem der DichterKriminalist schöpft erkennen. Es ist erstaunlich, in wie seiner Weise Wulffen seine wissenschaftlichen Quellen ausgebeutet hat, wie er die Wirklichkeit dichterisch gestaltet hat, ohne doch dadurch der kriminalpsychologischen Bedeutung seiner Schilderung irgendwie Abbruch zu tun.' SLUB, Nachlass des Schriftstellers und Kriminalisten Min.-Direktor Dr Erich Wulffen (1862-1936): Signatur: Mscr. Dres. App. 1832, 1478, Albert Hellwig, 'Dichter und Hochstapler', Universum, undated. 
72 SLUB, Nachlass des Schriftstellers und Kriminalisten Min.-Direktor Dr Erich Wulffen (1862-1936): Signatur: Mscr. Dres. App. 1832, 1478, 'Erich Wulffen: Der Mann mit den sieben Masken', Dresdner Volkszeitung, 18 July 1917; 'Erich Wulffen: Der Mann mit den sieben Masken', Die neue Generation (issue number unclear) (1917), pp. 160-3. The quoted text (found at p. 162) is: 'Es ist unwahrscheinlich, daß sich ein Staatsanwalt in so intime Reden mit einem überführten Verbrecher einlassen wird, daß er sich dessen psychologischen Beweggründe bis zum Vordeklamieren von Szenen aus Richard III. oder Hamlet erläutern lassen und daß er selbst so sehr in seinen Bann geraten wird, daß er schließlich, weil er sich als Ankläger besiegt fühlt, Selbstmord begeht.'

73 SLUB, Nachlass des Schriftstellers und Kriminalisten Min.-Direktor Dr Erich Wulffen (1862-1936): Signatur: Mscr. Dres. App. 1832, 1478, Dr Friedrich Morton, 'Der Mann mit den sieben Masken', Villacher Zeitung, 9 November 1917.

74 Greenacre, 'The Impostor', p. 360.

75 '[P]hysiologisch ... anders, ungünstiger ... organisiert.' Erich Wulffen, Irrwege des Eros. Mit einer Einleitung Mütter und Töchter (Hellerau bei Dresden: Avalun, 1929), p. 12.

76 SLUB, Nachlass des Schriftstellers und Kriminalisten Min.-Direktor Dr Erich Wulffen (1862-1936): Signatur: Mscr. Dres. App. 1832, 1407, Erich Wulffen, 'Weibliche Schöffen im Jugendgericht', undated; Erich Wulffen, Reformbestrebungen auf dem Gebiete des Strafvollzugs (Dresden: von Zahn \& Jaensch, 1905); Wulffen, Psychologie des Verbrechers, p. 269.

77 '[D]ie unbedingte, manchmal sklavische Hingebung an den Mann ihrer Wahl führt sie auf den verbrecherischen Weg.' Erich Wulffen, Der Sexualverbrecher. Ein Handbuch für Juristen, Verwaltungsbeamte und Ärzte (Groß-Lichterfelde Ost: Paul Langenscheidt, 1910), p. 362.

78 '[S]ie schien die Gelegenheit zu benutzen, den verflogenen Traum noch einmal zu durchleben.' Wulffen, Der Mann mit den sieben Masken, p. 147.

79 'Gerade das ausgesprochene Frauenschicksal, in Liebe nur einem einzigen Manne zu gehören, hatte sich an ihr in wunderbarer, erschütternder Weise erfüllt.' Wulffen, Der Mann mit den sieben Masken, p. 229.

80 See Lang, 'Influencing Public Knowledge', pp. 49-65.

81 SLUB, Nachlass des Schriftstellers und Kriminalisten Min.-Direktor Dr Erich Wulffen (1862-1936): Signatur: Mscr. Dres. App. 1832, 1477. The pronouncements 'die Kriminalpsychologie der Gegenwart..., eine Zierde nicht nur der deutschen kriminalistischen Literatur, sondern der kriminalistischen Weltliteratur' are found in Bernhard Weiß, 'Kriminalpsychologie', Die Polizei, no date available.

82 The DDP was founded by Parish priest and liberal politician Friedrich Naumann (1860-1919), German writer and publicist Theodor Wolff (1868-1943) and lawyer Hugo Preuss (1860-1925), the 'father of the Weimar constitution'. Prominent members constituted modern mandarins such as Bernhard Weiß, foreign minister Walther Rathenau (1867-1922) and sociologist Max Weber (1864-1920).

83 See for example Kurt Tucholsky, 'Old Bäumerhand, der Schrecken der Demokratie', in Gesammelte Werke in zehn Bänden, ed. Mary Gerold-Tucholsky and Fritz J. Raddatz, vol. IV (Reinbek bei Hamburg: Rowohlt Verlag, 1975), pp. $556-9$.

84 Elder, Murder Scenes, pp. 24-5, 95, 164-88; Hania Siebenpfeiffer, 'Böse Lust': Gewaltverbrechen in Diskursen der Weimarer Republik (Cologne: Böhlau, 2005), pp. 69-72; Karsten Uhl, Das 'verbrecherische Weib'. Geschlecht, Verbrechen und Strafen im kriminologischen Diskurs 1800-1945 (Münster: LIT, 2003), pp. 142-5.

85 Uhl, Das 'verbrecherische Weib', p. 115.

86 Elder, Murder Scenes, pp. 164-88.

87 Luke Springman, 'Poisoned Hearts, Diseased Minds, and American Pimps: The Language of Censorship in the Schund und Schmutz Debates', German Quarterly, 68:4 (1995), pp. 408-29, p. 408. 
88 'Von all diesen Dingen nähren sich zu viele, Alte und Junge.' Wulffen, Irrwege des Eros, p. 18.

89 Wulffen, Irrwege des Eros, pp. 6-9.

90 On the generation gap see Detlev Peukert, Weimar Germany (New York: Hill \& Wang, 1992), pp. 86-100.

91 Wulffen, Das Weib als Sexualverbrecherin, pp. 3-4.

92 See Wulffen, Das Weib als Sexualverbrecherin, pp. 10-23. Before Wulffen outlines the biological premises of criminality, his introduction surveys the attempts in Italian, French and Spanish criminological literature so far on the subject matter at hand: Lombroso's narrative of biologisation and generalisation; the French 'feminist' understanding of female criminality (exemplified through Camille Granier, born in 1858, who remains forgotten in the twenty-first century); the Spanish predominantly sociological understanding of criminality.

93 Wulffen, Das Weib als Sexualverbrecherin, p. 6. For the history of psychology in Germany, and the shift from empirical to experimental psychology, or from philosophy to science, see: Horst U. K. Gundlich, 'Germany', in David B. Baker, The Oxford Handbook of the History of Psychology: Global Perspectives (Oxford: Oxford University Press, 2012), pp. 255-88, especially pp. 267-74; Wulffen, Das Weib als Sexualverbrecherin, p. 8, 4.

94 SLUB, Nachlass des Schriftstellers und Kriminalisten Min.-Direktor Dr Erich Wulffen (1862-1936): Signatur: Mscr. Dres. App. 1832, Otto Juliusburger 'Das Weib als Sexualverbrecherin', Vorwärts, 15 February 1923, containing the phrase 'weibliche Kriminalität weniger als die männliche durch die sozialen Umstände hervorgerufen werde'.

95 SLUB, Nachlass des Schriftstellers und Kriminalisten Min.-Direktor Dr Erich Wulffen (1862-1936): Signatur: Mscr. Dres. App. 1832, 769, HRW publisher to Erich Wulffen, 12 August 1930. Wulffen eventually filed a law suit against Langenscheidt because of outstanding royalty payments, a sad end to what had been a successful partnership over more than two decades. With HRW he planned to release the third edition of Das Weib als Sexualverbrecherin and the twelfth edition of Sexualverbrecher.

96 SLUB, Nachlass des Schriftstellers und Kriminalisten Min.-Direktor Dr Erich Wulffen (1862-1936): Signatur: Mscr. Dres. App. 1832, 783, folio 1, HRW publisher to Erich Wulffen, 9 December 1930, containing the phrase 'in manchen Punkten etwas zu pessimistisch'.

97 SLUB, Nachlass des Schriftstellers und Kriminalisten Min.-Direktor Dr Erich Wulffen (1862-1936): Signatur: Mscr. Dres. App. 1832, 783, HRW publisher to Erich Wulffen, 9 December 1930, and 795, HRW publisher to Erich Wulffen, 28 April 1931. Wulffen commented in pencil on some of these suggestions. It has proved impossible to locate the third edition of Das Weib als Sexualverbrecherin, which is not held in any major library across the globe. As a consequence, it is impossible to check how much of this advice Wulffen and the publisher took on board for the third edition.

98 Lang, 'Influencing Public Knowledge', pp. 59-60.

99 '[U]nsere gesamte Geisteswelt sexuell geschwängert [wird] und Leser und Leserin erotisiert.' Wulffen, Irrwege des Eros, p. 12.

100 SLUB, Nachlass des Schriftstellers und Kriminalisten Min.-Direktor Dr Erich Wulffen (1862-1936): Signatur: Mscr. Dres. App. 1832, 456, Julius Brüll (Avalun publisher) to Erich Wulffen, 28 January 1927.

101 SLUB, Nachlass des Schriftstellers und Kriminalisten Min.-Direktor Dr Erich Wulffen (1862-1936): Signatur: Mscr. Dres. App. 1832, 783, HRW publisher to Erich Wulffen, 9 December 1930, containing the phrase 'ganz gut die doppelte Anzahl von Bildern untergebracht werden könnte, ohne dem Werk seinen wissenschaftlichen Charakter zu nehmen'.

102 SLUB, Nachlass des Schriftstellers und Kriminalisten Min.-Direktor Dr Erich 
Wulffen (1862-1936): Signatur: Mscr. Dres. App. 1832, 806, HRW publisher to Erich Wulffen, 24 November 1930, containing the phrases 'hundertmal so schwer wie früher'; 'lebhafte und auffallende Bilder'.

103 SLUB, Nachlass des Schriftstellers und Kriminalisten Min.-Direktor Dr Erich Wulffen (1862-1936): Signatur: Mscr. Dres. App. 1832, 804, Erich Wulffen to HRW publisher, 18 May 1931.

104 SLUB, Nachlass des Schriftstellers und Kriminalisten Min.-Direktor Dr Erich Wulffen (1862-1936): Signatur: Mscr. Dres. App. 1832, 787, HRW publisher to Erich Wulffen, 28 February 1931.

105 SLUB, Nachlass des Schriftstellers und Kriminalisten Min.-Direktor Dr Erich Wulffen (1862-1936): Signatur: Mscr. Dres. App. 1832, 791, Erich Wulffen to HRW publisher, 12 April 1931.

106 SLUB, Nachlass des Schriftstellers und Kriminalisten Min.-Direktor Dr Erich Wulffen (1862-1936): Signatur: Mscr. Dres. App. 1832, 791, Erich Wulffen to HRW publisher, 12 April 1931.

107 SLUB, Nachlass des Schriftstellers und Kriminalisten Min.-Direktor Dr Erich Wulffen (1862-1936): Signatur: Mscr. Dres. App. 1832, 791, Erich Wulffen to HRW publisher, 12 April 1931. Wulffen contributed to academic works on the history of photography with two major contributions: Die Erotik in der Photographie (1931) and 'Die behördliche Verfolgung des geheimen Photohandels', Die geschichtliche Entwicklung der Aktphotographie und des erotischen Lichtbildes und seine Beziehungen zur psychopathia sexualis (Vienna, Berlin, Leipzig: Verlag für Kulturforschung, 1931), pp. 187-210. See also Erich Wulffen and Felix Abraham, Fritz Ulbrichs lebender Marmor. Eine sexual-psychologische Untersuchung (Vienna, Berlin, Leipzig: Verlag für Kulturforschung, 1931). For the analysis of the self-perception of sexologists in this context, see Birgit Lang, 'Die Erotik in der Photographie: Zum Habitus von Sexualwissenschaftern', LiTheS. Zeitschrift für Literatur und Theatersoziologie, 5 (2010), pp. 5-24.

108 SLUB, Nachlass des Schriftstellers und Kriminalisten Min.-Direktor Dr Erich Wulffen (1862-1936): Signatur: Mscr. Dres. App. 1832, 791, Erich Wulffen to HRW publisher, 12 April 1931.

109 SLUB, Nachlass des Schriftstellers und Kriminalisten Min.-Direktor Dr Erich Wulffen (1862-1936): Signatur: Mscr. Dres. App. 1832, 797, Erich Wulffen to HRW publisher, 18 May 1931.

110 SLUB, Nachlass des Schriftstellers und Kriminalisten Min.-Direktor Dr Erich Wulffen (1862-1936): Signatur: Mscr. Dres. App. 1832, 797, Erich Wulffen to HRW publisher, 18 May 1931; also 810, HRW publisher to Wulffen, 14 September 1931 .

111 Other works include by Robert Heymann include Sexualwahn (with Otto Warneyer and Walter Bahn) (1928); Sing-sang der Liebe; ein buntes Buch von Liedern, Ludern und Lastern (1928); Weiber, Könige, Henker. Roman (1928); Christinens Weg durch die Hölle. Roman (1929); Das Verbrechen (1930); Ein Weib, ein Narr, ein Mörder (1930); Der masochistische Mann (1931); Die hörige Frau (1931); Sexuelle Hörigkeit (1931); Das hemmungslose Mädchen. Roman (1932); Nimm mich zu dir (1933).

112 '[H]at wenig Anspruch auf Sympathie.' Alfred Polgar, 'Ein Kriminalfall (1924)', in Edith Cadivec, Bekenntnisse und Erlebnisse (Munich: Belleville, 2008), pp. $357-58$, p. 357.

113 SLUB, Nachlass des Schriftstellers und Kriminalisten Min.-Direktor Dr Erich Wulffen (1862-1936): Signatur: Mscr. Dres. App. 1832, 159, Edith Christally to Erich Wulffen, 2 June 1932, containing the phrase 'Wissen täuscht und betrügt. Die Wahrheit ist die, die man erlebt'. Note that Cadivec changed her second name to Christally after her conviction in 1927.

114 Cadivec, Bekenntnisse und Erlebnisse, p. iv.

115 SLUB, Nachlass des Schriftstellers und Kriminalisten Min.-Direktor Dr Erich 
Wulffen (1862-1936): Signatur: Mscr. Dres. App. 1832, 159, Edith Christally to Erich Wulffen, 2 June 1932.

116 Armand Coppens, 'Memoiren eines Erotica-Händlers (1969)', in Cadivec, Bekenntnisse und Erlebnisse, pp. 443-6, p. 445; 'Bibliographische Verweise', in Cadivec, Bekenntnisse und Erlebnisse, pp. 447-51.

117 Cadivec, Bekenntnisse und Erlebnisse, p. iv.

118 Wulffen, Irrwege des Eros, p. 277. The psychiatric report is missing in the Viennese case files.

119 'Attest des Psychoanalytikers Ludwig Jekels für Walter Taussig', in Cadivec, Bekenntnisse und Erlebnisse, p. 442.

120 ' $[\mathrm{M}]$ it Hilfe der Auto- und Fremdsuggestion sich eine Auffassung gebildet habe, die ihre Handlungsweise mit der Moral zu versöhnen suche.' Wulffen, Irrwege des Eros, p. 277.

121 Neda Bei, 'Zum Strafverfahren gegen Edith Cadivec im Wiener "Sadistenprozess", 1924 (2005/2007)', in Cadivec, Bekenntnisse und Erlebnisse, pp. 397-428, p. 414.

122 Wulffen, Manolescu, p. 108.

123 SLUB, Nachlass des Schriftstellers und Kriminalisten Min.-Direktor Dr Erich Wulffen (1862-1936): Signatur: Mscr. Dres. App. 1832, 1448, 'Hochstaplerrache am Staatsanwalt', Deutsche Allgemeine Zeitung, 30 March 1923; 'Fall Engel', undated.

124 SLUB, Nachlass des Schriftstellers und Kriminalisten Min.-Direktor Dr Erich Wulffen (1862-1936): Signatur: Mscr. Dres. App. 1832, 974, Erich Wulffen, 'Siegmund $[s i c]$ Freud', where the German reads: 'Vor allem ist es die sexuelle Lockung, welche die ganze Theorie umgaukelt. Die Behauptung, all unser Fühlen und Denken und jede Deutung unserer Zustände und unseres Verhaltens habe sexuellen Zusammenhang, hat für den Menschen ganz allgemein und besonders in der Gegenwart eine ausserordentliche Anziehung. Dass darin ein krasser Materialismus steckt, wird kaum bemerkt. Dasein und Leben werden im Höchstmass erotisiert, sexualisiert zu einer Zeit, da alle sonstigen Reizmittel versagen. Die Übererotisierung, die Übersexualisierung, an der die Gegenwart leidet, sind zu einem Hauptteil der Freudschen Lehre mit zuzuschreiben'.

125 Juliusburger, 'Der Sexualverbrecher', p. 259.

126 Erich Wulffen, Shakespeares Hamlet. Ein Sexualproblem (Berlin: Duncker, 1913).

127 SLUB, Nachlass des Schriftstellers und Kriminalisten Min.-Direktor Dr Erich Wulffen (1862-1936): Signatur: Mscr. Dres. App. 1832, 1478, Otto Juliusburger, 'Enzyklopädie der Kriminalistik [Review of Sexualverbrecherin]', Fortschritte der Medizin, 13 May 1932, p. 419; a similar concern was raised in the forum Psychiatrische-neurologische Wochenschrift, 9 April 1932.

128 Erich Wulffen, 'Siegmund Freud'.

129 '[F]ür alle möglichen Auslegungen empfänglich.' Wulffen, 'Siegmund Freud'.

130 SLUB, Nachlass des Schriftstellers und Kriminalisten Min.-Direktor Dr Erich Wulffen (1862-1936): Signatur: Mscr. Dres. App. 1832, 1495, Friedrich Harth to Erich Wulffen, 19 July 1932, containing the phrase 'ergriffen und aufgerüttelt' and 'Seelenrätsel'. 